\title{
Mechanisms of Dopamine D1 Receptor-Mediated ERK1/2 Activation in the Parkinsonian Striatum and Their Modulation by Metabotropic Glutamate Receptor Type 5
}

\author{
Tim Fieblinger, ${ }^{1}$ Irene Sebastianutto, ${ }^{1}$ Cristina Alcacer, ${ }^{1}$ Zisis Bimpisidis, ${ }^{1}$ Natallia Maslava, ${ }^{1}$ Sabina Sandberg, ${ }^{1}$ \\ David Engblom, ${ }^{2}$ and M. Angela Cenci ${ }^{1}$ \\ ${ }^{1}$ Basal Ganglia Pathophysiology Unit, Department Experimental Medical Sciences, Lund University, BMC F11, 22184 Lund, Sweden, and ${ }^{2}$ Department of \\ Clinical and Experimental Medicine, Linköping University, Linköping, Sweden
}

\begin{abstract}
In animal models of Parkinson's disease, striatal overactivation of ERK1/2 via dopamine (DA) D1 receptors is the hallmark of a supersensitive molecular response associated with dyskinetic behaviors. Here we investigate the pathways involved in D1 receptor-dependent ERK1/2 activation using acute striatal slices from rodents with unilateral 6-hydroxydopamine (6-OHDA) lesions. Application of the dopamine D1-like receptor agonist SKF38393 induced ERK1/2 phosphorylation and downstream signaling in the DA-denervated but not the intact striatum. This response was mediated through a canonical D1R/PKA/MEK1/2 pathway and independent of ionotropic glutamate receptors but blocked by antagonists of L-type calcium channels. Coapplication of an antagonist of metabotropic glutamate receptor type 5 (mGluR5) or its downstream signaling molecules (PLC, PKC, IP 3 receptors) markedly attenuated SKF38393-induced ERK1/2 activation. The role of striatal mGluR5 in D1-dependent ERK1/2 activation was confirmed in vivo in 6-OHDA-lesioned animals treated systemically with SKF38393. In one experiment, local infusion of the mGluR5 antagonist MTEP in the DA-denervated rat striatum attenuated the activation of ERK1/2 signaling by SKF38393. In another experiment, 6-OHDA lesions were applied to transgenic mice with a cell-specific knockdown of mGluR5 in D1 receptor-expressing neurons. These mice showed a blunted striatal ERK1/2 activation in response to SFK38393 treatment. Our results reveal that D1-dependent ERK1/2 activation in the DA-denervated striatum depends on a complex interaction between PKA- and $\mathrm{Ca}^{2+}$-dependent signaling pathways that is critically modulated by striatal mGluR5.
\end{abstract}

Key words: D1 receptor; dopamine; ERK1/2; mGluR5; Parkinson's disease; striatum

\section{Introduction}

Phosphorylation of extracellular signal-regulated kinases 1 and 2 (ERK1/2) is triggered in neurons by different external stimuli, including neurotransmitters and growth factors, leading to a wide range of plastic responses through activation of cytosolic and nuclear targets (Mazzucchelli et al., 2002; Wiegert and Bading, 2011; Girault, 2012). In the striatum, a large activation of ERK1/2 has been associated with maladaptive plastic changes after either treatment with cocaine to intact animals (Girault et

Received June 26, 2013; revised Feb. 4, 2014; accepted Feb. 24, 2014.

Author contributions: T.F. and M.A.C. designed research; T.F., I.S., C.A., Z.B., N.M., and S.S. performed research; D.E. contributed unpublished reagents/analytic tools; T.F., I.S., C.A., Z.B., and N.M. analyzed data; T.F. and M.A.C. wrote the paper.

This work was supported by the Swedish Research Council to M.A.C. and D.E.; the EurCommunity's Seventh Framework Programme FP7 (REPLACES, Contract 22918; NEUROMODEL, Contract 215618; and TreatPolyQ, Contract 264508) to M.A.C., the Basal Ganglia Disorders Linnaeus Consortium, the Swedish Foundation for International Cooperation in Research and Higher Education, the Åhlen Foundation, the Greta and Johan Kocks Foundation, and the Olle Engkvist Foundation. We thank Ann-Christin Lindh for excellent technical assistance and Prof. Günther Schütz for providing access to the mGluR5 knockdown mouse line.

The authors declare no competing financial interests.

Correspondence should be addressed to either Dr. Tim Fieblinger or Dr. M. Angela Cenci, Basal Ganglia Pathophysiology Unit, Department Experimental Medical Sciences, Lund University, BMC F11, 22184 Lund, Sweden. E-mail: Tim.Fieblinger@med.lu.se or Angela.Cenci_Nilsson@med.lu.se.

DOI:10.1523/JNEUROSCI.2702-13.2014

Copyright $\odot 2014$ the authors $\quad 0270-6474 / 14 / 344728-13 \$ 15.00 / 0$ al., 2007; Fasano et al., 2009; Pascoli et al., 2011) or treatment with L-DOPA to dopamine (DA)-denervated animals (for review, see Cenci and Konradi, 2010). Under both conditions, striatal ERK1/2 activation depends on D1 receptors (D1R), but the downstream mechanisms are not fully understood.

Various observations suggest that different pathways may regulate D1R-dependent ERK1/2 activation in the intact versus the DA-denervated striatum. Although cocaine-induced ERK1/2 phosphorylation is prevented by systemic injection of an NMDA receptor antagonist (Valjent et al., 2000; Pascoli et al., 2011), the same treatment is ineffective in preventing D1R-mediated ERK1/2 phosphorylation in the DA-denervated striatum (Gerfen et al., 2002; Rylander et al., 2009). It is further unknown whether the modulatory effects of glutamate receptor antagonists on D1dependent ERK1/2 activation are mediated directly in the striatum or through other brain regions.

Understanding the mechanisms of D1R-mediated ERK1/2 activation in the DA-denervated striatum is particularly relevant to the study of L-DOPA-induced dyskinesia (LID), which is a major complication of the pharmacotherapy of Parkinson's disease (PD) (Manson et al., 2012). In parkinsonian rodents treated chronically with L-DOPA, the occurrence of dyskinetic behaviors is strongly correlated with a large activation of ERK1/2 signaling in DA-denervated striatal neurons via the D1R (Westin et al., 
2007; Darmopil et al., 2009; Santini et al., 2009). Treatments capable of blunting the striatal activation of ERK1/2 by L-DOPA consistently attenuate the severity of dyskinesia in mouse, rat, and monkey models of PD (Santini et al., 2007; Schuster et al., 2008; Rylander et al., 2009; Fasano et al., 2010). L-DOPA-induced overactivation of ERK1/2 signaling is therefore widely considered as a hallmark of the maladaptive molecular plasticity associated with LID (Darmopil et al., 2009; Cenci and Konradi, 2010; Alcacer et al., 2012). Understanding how ERK1/2 activation is regulated in a DA-denervated striatum may therefore lay the groundwork to identify novel antidyskinetic treatments.

In this study, we set out to investigate the mechanisms and modulation of ERK1/2 activation in the DA-denervated striatum. To exclude mechanisms mediated through other brain regions, we used acute striatal slices, an ex vivo model incorporating mature neurons in DA-denervated or native conditions. Our findings show that, in the DA-denervated striatum, D1R-mediated ERK1/2 activation is independent of ionotropic glutamatergic receptors and instead sensitive to inhibition of metabotropic glutamate receptor type 5 (mGluR5) and related intracellular signaling pathways. Using complementary in vivo approaches in DA-denervated animals, we finally demonstrate that D1R-dependent ERK1/2 signaling activation in the lateral (motor) part of the striatum critically depends on local mGluR5 activity.

\section{Materials and Methods}

Animals. Female Sprague Dawley rats (Harlan) and the bacterial artificial chromosome (BAC) transgenic mouse lines, Drd1a-tdTomato (Shuen et al., 2008) and $m G l u R 5^{K D-D 1}$ (Novak et al., 2010) (bred and provided by D. Engblom, Linköping University) were housed in a $12 \mathrm{~h}$ dark-light cycle with food and water ad libitum. Rats weighed 225-250 g at the beginning of the study. Mice were all on C57BL/6 background, $\sim 10$ weeks old at the beginning of the experiments, and both genders were used. All experiments were performed under approval by the MalmöLund Ethical Committee on Animal Research or the Animal Ethics Committee in Linköping.

Chemicals. Names of chemicals are given using their standard abbreviated form. EGTA, KT5720, CNQX, TTX, MK801, U0126, PP-2, U73122, ryanodine, 2-APB, BAPTA-AM, DHPG, QX-314, and GF109203X were purchased from Tocris Bioscience. MTEP was purchased at Abcam. SKF38393, picrotoxin, SCH23390, 6-hydroxydopamine-HCl (6-OHDA), ATP-Mg, GTP-Na, TEA-Cl, CsMeSO isradipine, and all other chemicals were purchased from Sigma-Aldrich.

6-Hydroxydopamine lesions. Chronic DA denervations were produced through 6-OHDA lesions in the medial forebrain bundle (MFB) according to well-established methods (Cenci and Lundblad, 2007; Francardo et al., 2011).

In brief, rats were anesthetized with a mixture of fentanyl and Dormitor (20:1, Apoteksbolaget), and 6-OHDA (Sigma Aldrich), dissolved in $0.02 \%$ ascorbate-saline, was stereotactically injected at a concentration of $3.5 \mu \mathrm{g} / \mu \mathrm{l}$ at the following coordinates: first injection $\mathrm{A}=-4.4, \mathrm{~L}=-1.2$, $\mathrm{V}=7-8$, tooth bar $=2.4(2.5 \mu \mathrm{l})$; second injection: $\mathrm{A}=-4.0, \mathrm{~L}=-0.8$, $\mathrm{V}=-8.0$, tooth bar $=3.4(2 \mu \mathrm{l})$ (coordinates are given in millimeters, relative to bregma and the dural surface). For postoperative analgesia, rats were given Temgesic $(0.167 \mathrm{mg} / \mathrm{kg}$ body weight, Apoteksbolaget $)$ at the end of the surgery.

Mice were anesthetized with a mixture $4 \%$ isofluorane in air (Isobavet, Apoteksbolaget) and placed in a stereotaxic frame with a mouse adaptor (Kopf Instruments). 6-OHDA was dissolved at a fixed concentration of $3.2 \mu \mathrm{g} / \mu \mathrm{l}$ free-base in $0.02 \%$ ascorbate-saline, and a total volume $0.4 \mu \mathrm{l}$ was injected at the following coordinates: $\mathrm{A}=$ $-0.7, \mathrm{~L}=-1.2, \mathrm{~V}=-4.7$, tooth bar $=-4.0$. The analgesic Marcain (bupivacaine, $2.5 \mathrm{mg} / \mathrm{ml}$, AstraZeneca) was injected subcutaneously (10 $\mu \mathrm{l} / 10 \mathrm{~g}$ body weight) before the first skin incision. Postoperative care of the mice was performed according to our published methods (Francardo et al., 2011).

Behavioral tests were used to verify the efficacy of the DA denervation 2 weeks after lesion. To this end, forepaw use asymmetry in the cylinder test was assessed in mice (Francardo et al., 2011), whereas amphetamineinduced rotation was measured in rats. In the latter test, rats were recorded for $90 \mathrm{~min}$ after intraperitoneal injection of $2.5 \mathrm{mg} / \mathrm{kg}$ D-amphetamine (Sigma Aldrich). Only rats exhibiting $>5$ full turns/min toward the side ipsilateral to the toxin injection were considered DAdenervated (i.e., $>90 \%$ striatal DA depletion) (Carta et al., 2006).

The loss of striatal tyrosine hydroxylase was further documented by Western immunoblotting in a subset of animals used in the slice experiment, whereas the loss of nigral tyrosine hydroxylase-positive cells was verified immunohistochemically in all animals used in the in vivo part of the study. In all cases, the tyrosine hydroxylase signal on the side ipsilateral to the lesion was $<5 \%$ of that on the contralateral side.

Striatal slice preparation and treatments. On the day of the experiment, animals were anesthetized with pentobarbital $(240 \mathrm{mg} / \mathrm{kg}$ i.p.; Apoteksbolaget) and decapitated. Their brains were rapidly removed and placed on an ice-chilled surface. The cerebral hemispheres were separated, and slices were cut on a vibratome (VT1200S, Leica). Parasagittal slices (250$275 \mu \mathrm{m}$ ) were cut in ice-cold aCSF containing the following (in mM): 124 $\mathrm{NaCl}, 3 \mathrm{KCl}, 26 \mathrm{NaHCO}_{3}, 120 \mathrm{NaH}_{2} \mathrm{PO}_{4}, 2 \mathrm{CaCl}_{2}, 1 \mathrm{MgCl}_{2}$, and 16.66 glucose. The aCSF was at all times gassed $\left(5 \% / 95 \% \mathrm{O}_{2} / \mathrm{CO}_{2}\right)$ to maintain $\mathrm{pH} \sim 7.4$ and oxygenation. Osmolarity was frequently checked between experiments and was typically $300-310 \mathrm{mOsm} / \mathrm{L}$. Slices were immediately transferred into a dissection dish, and the striata were carefully dissected out in ice-cold aCSF. Striatal slices were then transferred into room temperature buffer and subsequently allowed to equilibrate at near physiological temperature $\left(34^{\circ} \mathrm{C}\right)$ for at least $45 \mathrm{~min}$.

One hemisphere typically yielded a total of seven striatal samples for the testing of different drugs of interest. These seven samples were then divided into two untreated control samples, two positive control samples (i.e., treatment with SKF38393), and three samples for combined treatments. For the treatments, the slices were transferred into test tubes containing $10 \mathrm{ml} \mathrm{aCSF}$ and were constantly gassed. For each condition, at least four samples $(n=4)$ were analyzed. In some cases, the aCSF was additionally modified as indicated in the text. In a preliminary experiment, we incubated DA-denervated slices with $0.1,1.0$, and $10 \mu \mathrm{M}$ SKF38393 for $7 \mathrm{~min}$, based on previous publications (Voulalas et al., 2005; Vastagh et al., 2012), with $10 \mu \mathrm{M}$ providing the most robust upregulation of phospho-ERK1/2, without having an effect on phosphoERK1/2 levels in the intact hemisphere or completely drug-naive rats. This concentration was therefore used in all the following experiments. All other compounds were used according to previously published concentrations and incubation times. Treatment durations and concentrations are listed in Table 1. Stock solutions of drugs of interest were made in water or DMSO, according to the manufacturers' instructions. Final DMSO concentration in the testing conditions never exceeded $0.1 \%$.

After the respective treatments, the buffer was removed and the samples rapidly frozen on dry ice before storage at $-80^{\circ} \mathrm{C}$.

Electrophysiology and two-photon imaging. For miniature EPSC (mEPSC) recordings, single striatal slices, prepared as described above, were placed in a submerged recording chamber and constantly perfused with aCSF at room temperature. Striatal spiny projection neurons (SPNs) were readily identified by their typical morphology and size. In slices from Drd1a-tdTomato BAC mice, D1R-expressing SPNs were further identified by the presence of red fluorescence. Recording pipettes (3-6 $\mathrm{M} \Omega$ when filled with internal solution) were pulled from thickwalled borosilicate glass $(1.5 \mathrm{~mm} \mathrm{OD}, 0.86 \mathrm{~mm}$ ID) with a FlamingBrown horizontal puller (P-97, Sutter Instruments). For recording of mEPSCs, the internal recording solution contained the following (in mM): $120 \mathrm{CsMeSO}_{3}, 5 \mathrm{NaCl}, 10$ TEA-Cl, 10 HEPES, 5 QX-314, 4 ATP$\mathrm{Mg}$, and 0.3 GTP-Na. The solution was adjusted to $\mathrm{pH} 7.2$ with $\mathrm{CsOH}$, and the osmolarity was $270-280 \mathrm{mOsm}$. Series resistance was regularly monitored via a $7 \mathrm{mV}$ voltage step, and recordings were rejected after changes of $>25 \%$. Cells were held at $-70 \mathrm{mV}$ in the presence of picrotoxin, TTX, and MK801, to isolate AMPA currents. Recordings were made for at least 3-5 min, sampled at $20 \mathrm{kHz}$ using a Multiclamp 700B 
Table 1. Compounds used to inhibit SKF38393-induced ERK1/2-signaling ${ }^{a}$

\begin{tabular}{lcll}
\hline & Concentration $(\mu \mathrm{M})$ & Duration $(\mathrm{min})$ & Biological activity \\
\hline SCH23390 & 10 & 15 & D1-like receptor antagonist \\
KT5720 & 0.5 & 30 & PKA antagonist \\
U0126 & 10 & 15 & MEK inhibitor \\
MK-801 & 10 & 15 & NMDA receptor antagonist \\
Ro25-6981 & 1 & 15 & NR2B subunit antagonist \\
Isradipine & 10 & 15 & L-type channel antagonist \\
PP-2 & 10 & 30 & Src kinase inhibitor \\
MTEP & 10 & 15 & mGluR5 antagonist \\
U73122 & 7.5 & 25 & PLC inhibitor \\
GF109203X & 1 & 30 & PKC inhibitor \\
2-APB & 50 & 45 & IP3 receptor antagonist \\
Ryanodine & 10 & 30 & Ryanodine receptor antagonist \\
BAPTA-AM & 20 & 30 & Cell-permeable calcium chelator \\
TTX & 1 & 15 & Sodium channel antagonist \\
Picrotoxin & 50 & 15 & GABA-A receptor antagonist \\
CNQX & 20 & 15 & AMPA receptor antagonist \\
\hline
\end{tabular}

${ }^{a}$ Different compounds were bath-applied to test their ability to inhibit SKF38393-induced ERK1/2 signaling or to modulate glutamatergic synaptic transmission. The table reports the compounds' concentrations and their incubation times before SKF38393 treatment. These parameters were carefully chosen based on the relevant literature.

amplifier (Molecular Devices) and converted using a Digidata 1440A digitizer (Molecular Devices). Miniature events were analyzed using Minianalysis software (Synaptosoft).

AlexaFluor-488 $(50 \mu \mathrm{M})$ was included in the internal solution during mEPSC experiments for postrecording visualization of the cell and final verification of the spiny neuron phenotype. Images were acquired on a LSM710 NLO laser scanning microscope (Zeiss), using a Ti:sapphire laser (MaiTai, Spectra Physics), set at an excitation wavelength of 750 $\mathrm{nm}$. The beam was focused on the slice through a $63 \times$ water-immersion objective (1.0 NA, Zeiss), and a $z$-stack of $80-100$ optical sections ( $1 \mu \mathrm{m}$ steps) was taken to document neuronal morphology.

Western immunoblotting. Striatal samples were homogenized in RIPAlysis buffer, containing $65 \mathrm{~mm}$ Tris-base, $150 \mathrm{~mm} \mathrm{NaCl}, 1 \%$ Triton-X, $0.25 \%$ sodium deoxycholate, $1 \mathrm{~mm}$ EDTA, and a mix of phosphatase and protease inhibitors ("phosSTOP" and "Complete, mini, EDTA-free," Roche Applied Science). Protein concentration was determined using a BCA Protein Assay Kit (Pierce \#23225, ThermoScientific). Equal amounts of protein (typically $10 \mu \mathrm{g}$ ) were loaded for each sample on a $10 \%$ SDS-polyacrylamide gel for separation and then transferred on a polyvinyldifluoride membrane. Membranes were blocked with 5\% nonfat dry milk and then incubated overnight using one of these antibodies:

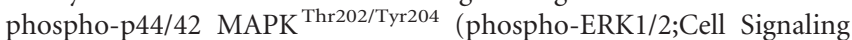
Technology, \#9101), p44/42 MAPK (total ERK1/2;Cell Signaling Technology, \#4695), phospho-GluA1 ${ }^{\text {Ser845 }}$ (Cell Signaling Technology, \#8084), GluA1 (Cell Signaling Technology, \#8850), phosphoMSK1 $^{\text {Ser360 (Abcam, ab81294), phospho-MEK1/2 }}{ }^{\text {Ser217/221 (Cell Signal- }}$ ing Technology, \#9121), tyrosine hydroxylase (Pel-Freez, P40101-0) or $\beta$-actin-peroxidase (Sigma, A-3854). After several washing steps, membranes were incubated with HRP-linked secondary antibodies: antibiotin, HRP-linked antibody (Cell Signaling Technology, \#7075); antirabbit IgG, HRP-linked (Cell Signaling Technology, \#7074); and signals were visualized by chemiluminescence using a ECL kit (Pierce, \#32106, ThermoScientific). The images were acquired using a CCD camera (LAS1000 system, Fuji Films) and analyzed using ImageJ (National Institutes of Health). After image acquisition, membranes were stripped and reblotted for loading controls.

Treatment of DA-denervated slices with SKF38393 did not change the levels of total ERK1/2 protein. Expressing the levels of phospho-ERK1/2 over total ERK1/2 (SKF: $211.1 \pm 11.59 \%$ of untreated control, $p<0.001$, $n=6$ ) did not differ from expressing them over actin levels. The signal of specific bands was therefore consistently normalized to their respective actin levels throughout the study.

Intrastriatal infusion of MTEP. Rats with successful 6-OHDA lesions were anesthetized with a mixture of isoflurane in air (Isoba vet., Apoteksbolaget, $3 \%$ induction and $1.5-2.5 \%$ maintenance of anesthesia) and placed in a stereotaxic apparatus (David Kopf Instruments). Microdialy- sis probes (AgnThos, AT4 series, membrane diameter: $200 \mu \mathrm{m}$, active membrane length $3 \mathrm{~mm}$ ) were implanted in the DA-denervated lateral striatum (A: 0.6 from bregma, L: 3.3 from midline, V: -6.0 from dura, tooth bar: -3.3$)$. The probes were anchored to the skull using jeweler screws and dental cement.

After $\sim 48 \mathrm{~h}$ of recovery, the animals were individually placed in custom-made microdialysis Plexiglas boxes and probes were connected through a swivel to a syringe pump providing modified Ringer's solution containing the following (in mM): $1.2 \mathrm{CaCl}_{2}, 2.7 \mathrm{KCl}, 148 \mathrm{NaCl} 148$, and $0.85 \mathrm{MgCl}_{2}$. The Ringer flow was kept constant at $3 \mu \mathrm{l} / \mathrm{min}$, and probes were rinsed for at least $1 \mathrm{~h}$ to establish tissue equilibrium. In the experimental group, the Ringer was switched, after the rinsing period, to a solution containing $1 \mathrm{~mm}$ MTEP. Based on the procedure used in other reverse dialysis studies (Li et al., 2011), the concentration of MTEP was chosen as being 100-fold larger than the effective concentration tested on the slices. Control animals received infusions of Ringer only. After drug infusions, the rats were treated with SKF38393 $(1.5 \mathrm{mg} / \mathrm{kg}$, s.c. $)$ or saline. Twenty-five minutes after the subcutaneous injection, the animals were anesthetized with pentobarbital $(240 \mathrm{mg} / \mathrm{kg}$ body weight i.p.; Apoteksbolaget) and transcardially perfused with 4\% PFA for immunohistochemistry.

Immunohistochemistry. Thirty minutes after SKF38393 injection, animals were anesthetized with pentobarbital and transcardially perfused with $4 \%$ ice-cold, buffered, $\mathrm{pH} 7.4$, PFA. After extraction, brains were postfixed for $2 \mathrm{~h}$ in $4 \%$ PFA before transferring them to buffered $25 \%$ sucrose solution for $24-36 \mathrm{~h}$. Coronal sections were cut on a freezing microtome at a thickness of $40 \mu \mathrm{m}$ (rats) or $30 \mu \mathrm{m}$ (mice). Free-floating sections containing either striatum or substantia nigra were stored in cryoprotective solution (30\% ethylene glycol and 30\% glycerol in $0.1 \mathrm{M}$ phosphate buffer) at $-20^{\circ} \mathrm{C}$ until further use.

Sections were kept on ice for phospho-ERK1/2 and phospho-H3 immunohistochemistry throughout all steps until the incubation with the secondary antibodies. In brief, after quenching endogenous peroxidase activity with $3 \% \mathrm{H}_{2} \mathrm{O}_{2}$ and $10 \%$ methanol, sections were blocked for $1 \mathrm{~h}$ in 5\% normal goat serum or 5\% normal donkey serum in Tris-buffered saline, supplemented with $\mathrm{NaF}(2 \mathrm{mg} / \mathrm{ml})$ as a phosphatase inhibitor. Incubation with primary antibodies was performed overnight at $4^{\circ} \mathrm{C}$. The primary antibody against phospho-ERK1/2 (Cell Signaling Technology, \#9101) was used at a dilution of 1:250; the antibody against phospho-H3 (anti-phospho-histone H3 ${ }^{\text {Ser10 }}$, Millipore, \#06-570) was diluted 1:500.

After a series of washing steps, the sections were incubated with secondary antibodies either coupled to Alexa-488 (Invitrogen, \#A11034) or Cy3 (Jackson Immunoresearch Laboratories, \#711-165-152), at 1:400 dilution, for $1 \mathrm{~h}$ at room temperature. Sections were mounted using VectaShield mounting media (Vector Laboratories).

Image acquisition and analysis. Confocal images of mounted sections were taken on a LSM710 NLO laser-scanning microscope, using a $20 \times$ objective ( $0.5 \mathrm{NA}$, Zeiss). Pictures were acquired in each region of interest (dorsolateral, dorsomedial, and ventrolateral striatum) from three sections per animal through the mid-part of the striatum. Single plane pictures or $z$-stacks of each region (typically of $30-50 \mu \mathrm{m}$ along the $z$-axis in $1 \mu \mathrm{m}$ steps) were acquired, and the analysis was performed on maximum projection images. For each animal, the three measurements from each region of interest were averaged to a single value. Quantification of phospho-ERK1/2 and phospho-H3 positive cells was done in an automated way using National Institutes of Health ImageJ (Alcacer et al., 2012). Analysis was performed on an area sizing $424.3 \times 424.3 \mu \mathrm{m}^{2}$, and data are presented as positive cells per $\mathrm{mm}^{2}$. Alexa- 488 was excited with $480 \mathrm{~nm}$ (filter 499-630), Cy3 with $514 \mathrm{~nm}$ (filter 538-681).

Overview confocal pictures of the DA-denervated and intact striatum were taken using a $4 \times$ objective. In rat sections, the areas adjacent to the track of the microdialysis probe were excluded from the cell count analysis.

Statistical analysis. Statistical analysis was performed using Prism 5 (GraphPad Software). Data were analyzed by one-way ANOVA and post hoc Bonferroni's Multiple Comparisons test. Two-group comparisons were made using a paired or unpaired Student's $t$ test, where appropriate. 


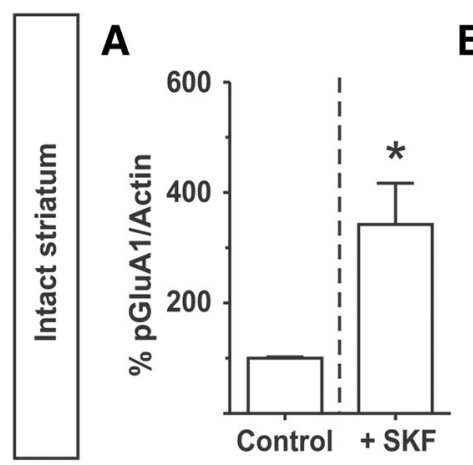

B

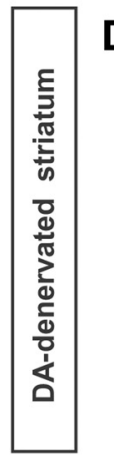

E

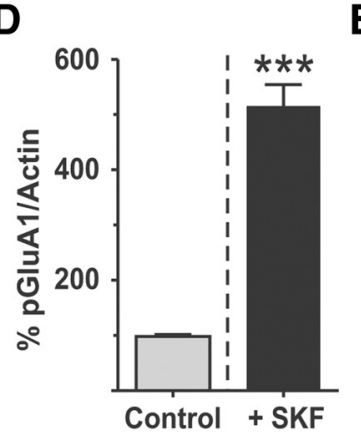

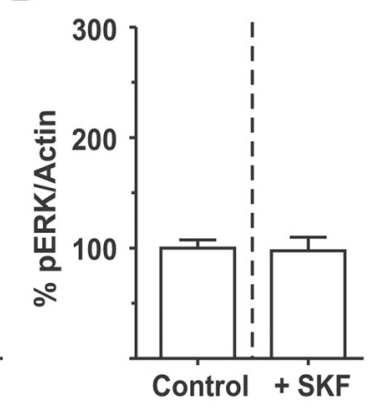

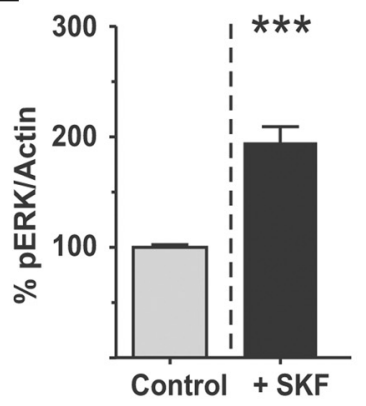

C

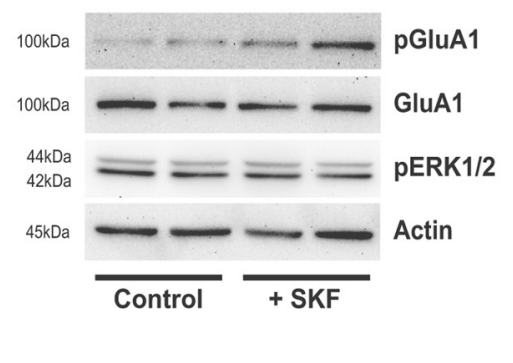

$\mathbf{F}$

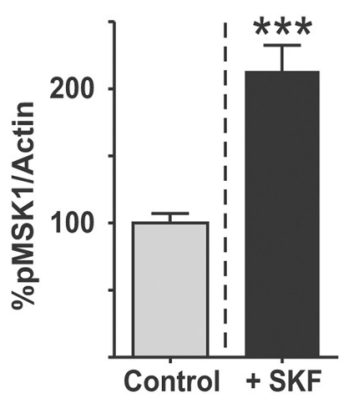

G

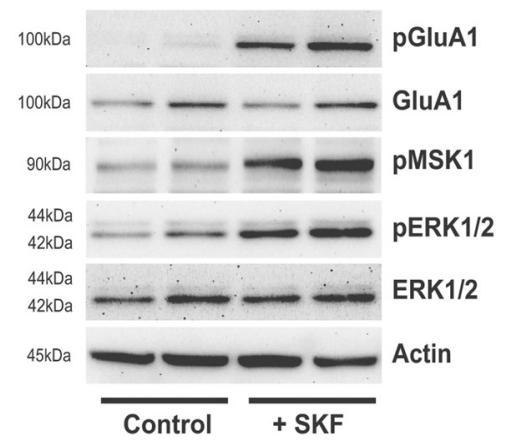

Figure 1. SKF38393 activates ERK1/2 signaling in slices from the DA-denervated striatum. $\boldsymbol{A}-\boldsymbol{C}$, Bath application of the D1R-agonist SKF38393 (10 $\mu \mathrm{m})$ increases Ser ${ }^{845}$ phosphorylation of the GluA1 AMPA-receptor subunit in the intact rat striatum $(\boldsymbol{A})$, without increasing the phosphorylation of ERK1/2 (B). ${ }^{*} p<0.05$ versus untreated control (unpaired Student's $t$ test). $n=4$. Representative blots are shown in $\boldsymbol{C}$. $\boldsymbol{D}-\boldsymbol{G}$, In the DA-denervated striatum, the same treatment induces phosphorylation of both GluA1 (D) and ERK1/2 (E). ${ }^{* *} p<0.001$ versus untreated control (unpaired Student's $t$ test). $n=17$. This increase in phospho-ERK1/2 is accompanied by activation of the downstream kinase MSK-1 $(\boldsymbol{F})$. ${ }^{* * *} p<0.001$ (unpaired Student's $t$ test). $n=8$. Representative blots are shown in $\boldsymbol{G}$.

The significance level was set at $p<0.05$. Data are presented as group mean \pm SEM.

\section{Results}

SKF38393 activates ERK1/2 only in DA-denervated striata

We used acute brain slices (Lindgren et al., 2002) from both intact and unilaterally 6-OHDA-lesioned rats to investigate D1Rmediated signaling in striata isolated from their anatomical network. Slices were incubated with the selective D1-like agonist SKF38393 (SKF, $10 \mu \mathrm{M}, 7 \mathrm{~min}$ ). Phosphorylation of the AMPA receptor subunit GluA1 at Ser ${ }^{845}$ was used as a marker of a signaling response mediated by protein kinase A (PKA) (Snyder et al., 2000) downstream of the D1R (Alcacer et al., 2012).

In untreated control slices from intact and DA-denervated striata, baseline levels of phospho-Ser ${ }^{845}$-GluA1 were almost undetectable (Fig. 1C,G). After SKF treatment, the levels of phospho-Ser ${ }^{845}$-GluA1 increased significantly in both intact and DA-denervated striata (Fig. $1 A, D$; intact: SKF: $342.2 \pm 74.81 \%$ of untreated controls, $p<0.05, n=4$; DA-denervated: SKF: $515.6 \pm 38.58 \%$ of untreated controls, $p<0.001, n=17$ ). These data indicate that, under our experimental conditions, SKF38393 treatment activates the canonical adenylate cyclase/PKA pathway in both intact and DA-denervated slices.

We subsequently examined the levels of ERK1/2 phosphorylation at $\mathrm{Thr}^{202} / \mathrm{Tyr}^{204}$ (phospho-ERK1/2). Baseline levels of phospho-ERK1/2 were readily detected in both intact and DAdenervated striatal slices (Fig. $1 C, G$ ). Treatment with SKF did not increase phospho-ERK1/2 levels in intact striatal slices (Fig. 1B) yet produced a large increase in the DA-denervated striata (Fig. $1 E$; SKF: $194.9 \pm 14.38 \%$ of untreated control, $p<0.001, n=$ $6-11)$. A similar pattern of effects was obtained upon direct slice application of dopamine $(50 \mu \mathrm{M})(215.6 \pm 13.05 \%$ of untreated control in DA-denervated striata; $p<0.001, n=6-8 ; 109.7 \pm$ $5.62 \%$ of untreated control in intact striata; $p>0.05, n=6-8$ ).

In animal models of PD, D1R-dependent ERK1/2 activation in the DA-denervated striatum is accompanied by phosphorylation of nuclear targets, such as mitogen- and stress-activated protein kinase 1 (MSK1) and histone H3 (Westin et al., 2007; Santini et al., 2009; Alcacer et al., 2012). To verify whether ERK1/2 phosphorylation led to activation of downstream nuclear targets also in our ex vivo setting, we measured the levels of MSK1 phosphorylated at Ser ${ }^{360}$, an ERK-specific phosphorylation site (McCoy et al., 2005). In slices from DA-denervated animals, SKF treatment indeed induced a large increase in phosphoSer ${ }^{360}$ MSK1 (Fig. $1 F, G$; SKF: $213.3 \pm 19.18 \%$ of untreated control, $p<0.001, n=8)$.

\section{D1R agonist-induced ERK1/2 activation is dependent on the} canonical signaling pathway

In animal models of PD, striatal D1R-dependent ERK1/2 activation depends on the canonical PKA signaling pathway and on mitogen-activated protein kinase kinase (MEK1/2) (Santini et al., 2007; Lebel et al., 2010). To test whether this also applies to our ex vivo setting, striatal slices from DA-denervated animals were incubated with either the selective D1-like antagonist SCH23390 $(10 \mu \mathrm{M})$, the specific PKA inhibitor KT5720 $(0.5 \mu \mathrm{M})$, or the MEK1/2 inhibitor U0126 $(10 \mu \mathrm{M})$ before applying SKF38393. The samples were then analyzed for levels of phosphoGluA1 ${ }^{\text {Ser845 }}$, phospho-MEK1/2 ${ }^{\text {Ser217/222 }}$, and phospho-ERK1/ $2^{\text {Thr202/Tyr204. Each of these was increased in the DA-denervated }}$ striatum after SKF treatment, and the effect was completely 
A

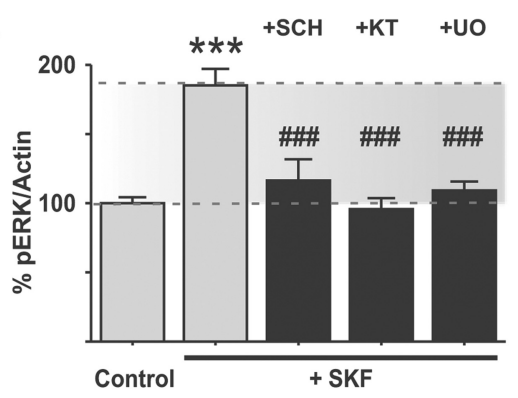

B

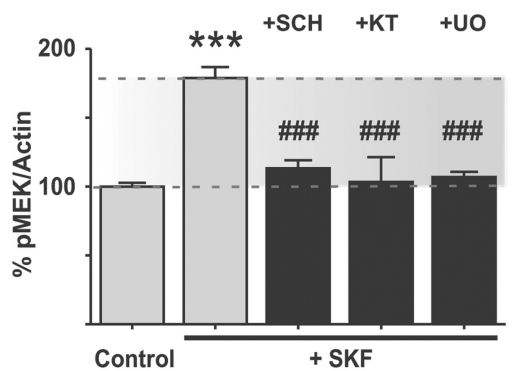

C

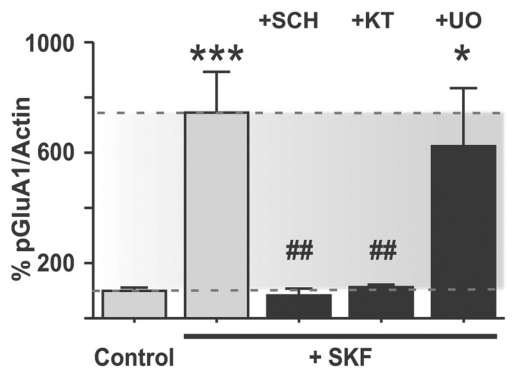

D

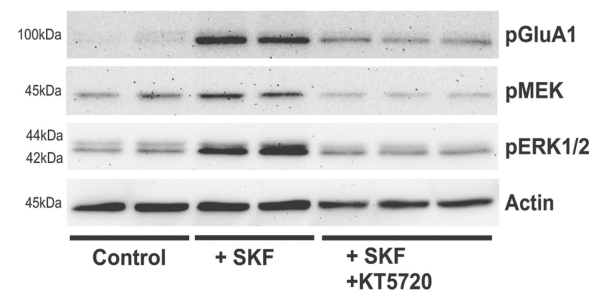

Figure 2. SKF38393 induces ERK1/2 activation in the DA-denervated striatum via canonical signaling mediators. A-D, Bath application of the D1R-agonist SKF38393 induces phosphorylation of GluA1, MEK1/2, and ERK1/2 in the DA-denervated striatum. The D1R-antagonist SCH23390, the PKA inhibitor KT5720, and the MEK1/2 inhibitor U0126 prevent the increase in ERK1/2 phosphorylation $(\boldsymbol{A})$ and MEK1/2 phosphorylation $(\boldsymbol{B}){ }^{* * *} p<0.001$ versus untreated control (Bonferroni's multiple comparison test). \#\#\#p $<0.001$ versus SKF treatment (Bonferroni's multiple comparison test). $n=6-14$. However, PKAdependent phosphorylation of GluA1 by SKF38393 was only blocked by the D1Rantagonist or PKA-inhibitor and unaffected by MEK1/2 inhibition (C). ${ }^{* *} p<0.001$ versus untreated control (Bonferroni's Multiple Comparison test). ${ }^{*} p<0.05$ versus untreated control (Bonferroni's Multiple Comparison test). ${ }^{\# \#} p<0.01$ versus SKF treatment (Bonferroni's Multiple Comparison test). $n=6-12$, placing PKA activity upstream of MEK1/2 in the cascade of ERK1/2 activation. Representative blots depicting the effect of PKA-inhibition on SKF38393-induced signaling responses are shown in $\boldsymbol{D}$.

blocked by either the D1R-antagonist or the PKA inhibitor (Fig. $2 A-D)$. Inhibition of MEK1/2 with U0126 did not affect the PKAmediated phosphorylation of GluA1 (Fig. $2 C$ ) but prevented activation of MEK1/2 and ERK1/2 (Fig. $2 A, B$ ).

The effect of U0126 on D1R agonist-induced phosphoERK1/2 is quite in line with in vivo studies performed in
6-OHDA-lesioned rats (Gerfen et al., 2002); this study, however, did not examine whether MEK inhibitors also affected the levels of phospho-MEK1/2 itself. An effect of U0126 in preventing MEK1 activation has been reported in previous studies (Davies et al., 2000; Bain et al., 2007) and may depend on positive feedback features of MEK-ERK signaling networks (Bhalla and Iyengar, 1999; Kocieniewski and Lipniacki, 2013). This topic, however, goes beyond the scope of the present work. Here it is important to emphasize that the lack of effect of U0126 on phosphoGluA1 ${ }^{\text {Ser845 }}$ in the presence of significant MEK-ERK inhibition indicates that activation of MEK-ERK by the D1R agonist occurs downstream of PKA.

The results thus far indicate that, at a concentration sufficient to activate PKA in both intact and DA-denervated slices, SKF38393 induces a D1R-mediated and PKA-dependent activation of ERK1/2 signaling via MEK1/2 specifically in the DAdenervated striata. This is in accordance with results obtained in vivo in unilaterally 6-OHDA-lesioned rodents treated with either D1R agonists or L-DOPA (Gerfen et al., 2002; Santini et al., 2007; Westin et al., 2007; Lebel et al., 2010).

\section{D1R agonist-induced ERK1/2 activation is independent of glutamatergic synaptic transmission via iGluR}

Excitatory glutamatergic synaptic transmission is the major input to striatal neurons (Gerfen and Surmeier, 2011) and an important route to MAPK signaling activation (Sgambato et al., 1998; Mao et al., 2004). Moreover, DA-dependent ERK1/2 phosphorylation has been shown to depend on ionotropic glutamate receptors (iGluR) in intact animals (Jiao et al., 2007; Nishi et al., 2011; Pascoli et al., 2011), and AMPA receptor subunit phosphorylation may lead to a potentiation of glutamatergic synaptic transmission (Lee et al., 2000, 2003; Lu and Roche, 2012; Oliveira et al., 2012). These considerations prompted the question whether the activation of ERK1/2 signaling by SKF38393 may depend on an enhancement of spontaneous excitatory synaptic transmission. We addressed this question using whole-cell patchclamp recordings from striatal SPNs in the slice preparation (Fig. $3 A, C, E)$. Cells were held at a hyperpolarized potential $(-70 \mathrm{mV})$ in the presence of TTX $(1 \mu \mathrm{M})$, picrotoxin (Ptx, $50 \mu \mathrm{M})$, and MK801 $(10 \mu \mathrm{M})$ to selectively record spontaneous miniature currents (mEPSCs). Even though cortex and thalamus are removed in this slice preparation, AMPA receptor-mediated events were readily detected at $\sim 2-3 \mathrm{~Hz}$ (Fig. $3 E$, traces) and were completely blocked by CNQX ( $n=5$; data not shown).

Application of SKF38393 (10 $\mu \mathrm{M}, 7 \mathrm{~min})$ did not change the average frequency of AMPA events in the DA-denervated rat striatum (Fig. $3 B$; before SKF: $2.45 \pm 0.56 \mathrm{~Hz}$, after SKF: $2.24 \pm$ $0.37 \mathrm{~Hz}, p>0.05)$ nor the pattern of glutamate release, as indicated by the interevent intervals (data not shown). However, a small reduction in the amplitude of AMPA currents was observed (Fig. 3B). Because D1R are only expressed in one population of SPNs, we repeated this experiment in slices from 6-OHDA-lesioned mice expressing a reporter-fluorophore under control of the D1R-promotor (Drd1a-tdTomato BAC mice). D1R-expressing SPNs were identified by the presence of red fluorescence (Fig. 3C). Confirming the findings from 6-OHDA-lesioned rats, SKF38393 had no effect on AMPA mEPSC frequency, and it did not affect the mEPSC amplitude in D1R-positive SPNs (Fig. 3D).

To further assess whether iGluRs may be involved in SKFinduced ERK1/2 activation, slices from DA-denervated rats were incubated either with the broad spectrum, noncompetitive NMDA receptor antagonist MK801 $(10 \mu \mathrm{M})$ or with the selective 
A

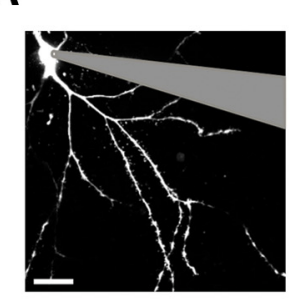

B

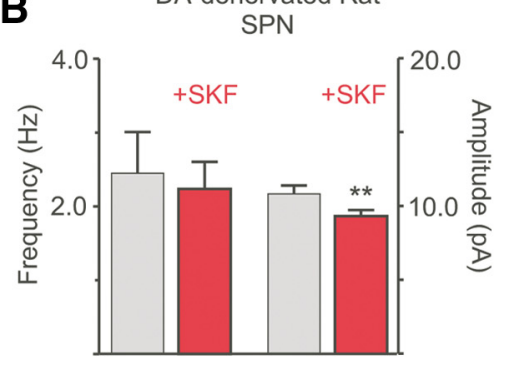

C

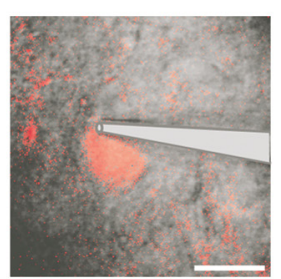

D

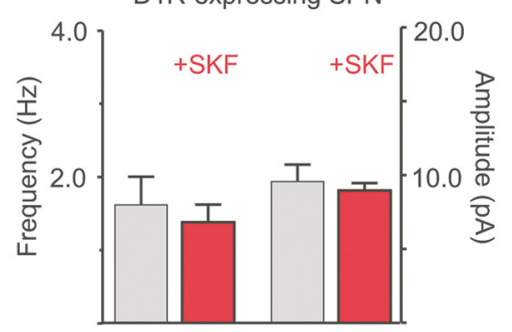

E

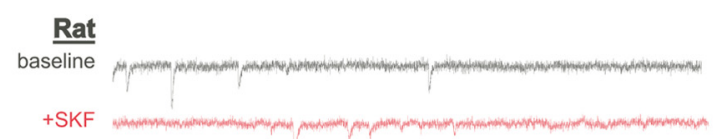

Mouse

baseline

+ SKF

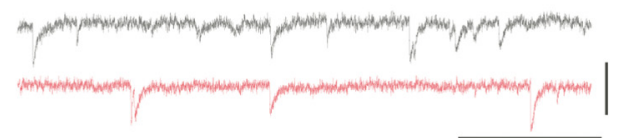

$\mathbf{F}$

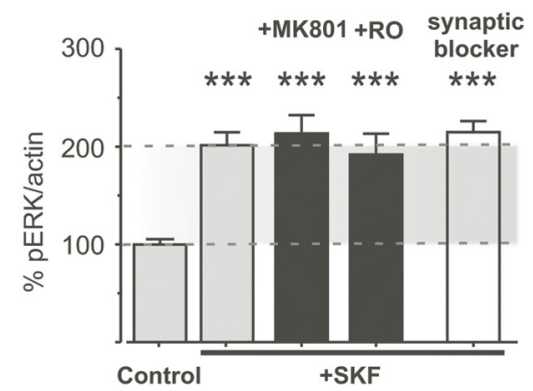

Figure 3. SKF38393-induced ERK1/2 phosphorylation in the DA-denervated striatum is independent of iGluR-transmission. $A-E$, A patched and dye-filled SPN from a rat slice is shown in A. SKF38393 did not induce any significant change in mEPSC frequency and only a small change in amplitude $(\boldsymbol{B}) .{ }^{* *} p<0.01$ (paired Student's t test, $n=10$ ). A Drd 1a-tdTomato-positive SPN in a mouse slice is shown in C. SKF38393 did not have any significant effect in the recordings from these neurons $(\boldsymbol{D})(p>0.05$, paired Student's t test, $n=7)$. Scale bar, $10 \mu \mathrm{m}$. Representative traces before and after $S K 38393$ are shown in $E$. Calibration: $20 \mathrm{pA}$ and $0.5 \mathrm{~s}$. $\boldsymbol{F}$, Neither MK801 nor the NR2B-antagonist R0256981 reduces SKF38393-induced phospho-ERK1/2 levels in the DA-denervated striatum. Total blockade of synaptic transmission "synaptic blocker," TTX, Ptx, MK801, CNQX) has no effect either $(\boldsymbol{F}) .{ }^{* * *} p<0.001$ versus untreated control (Bonferroni's Multiple Comparison test, $n=7-18$ ).

inhibitor of the highly $\mathrm{Ca}^{2+}$-permeable NR2B subunit, Ro25$6981(1 \mu \mathrm{M})$. The SKF-induced increase in phospho-ERK1/2 levels was unaffected by the above treatments (Fig. 3F; SKF+MK801: $213.7 \pm 18.47 \%$, SKF+RO: $192.1 \pm 21.18 \%$ of untreated controls, $p>0.05$ vs SKF alone) and was also unaffected by a complete blockade of iGluR synaptic transmission through combined application of TTX, Ptx, CNQX, and MK801 (Fig. 3F; SKF+ "synaptic blocker": $215.0 \pm 11.20 \%$ of untreated control, $p>0.05$ vs SKF alone, $n=7-18$ ).
Together, these data indicate that the SKF-induced activation of ERK1/2 signaling in DA-denervated slices is independent of changes in glutamatergic synaptic transmission and does not require NMDA receptor activity.

\section{$\mathrm{Ca}^{2+}$ and Src kinases are required for D1R agonist-induced ERK1/2 phosphorylation}

Increases in intracellular $\mathrm{Ca}^{2+}$ concentrations are a prerequisite for activation of mitogen-activated protein kinases (MAPK) in many cells (Rosen et al., 1994; Egea et al., 1999; Mulvaney et al., 1999). To verify the requirement of extracellular $\mathrm{Ca}^{2+}$ for D1Rmediated ERK1/2 activation, SKF38393 was applied to slices kept in a $\mathrm{Ca}^{2+}$-free buffer (modified aCSF with $0 \mathrm{mM} \mathrm{Ca}^{2+}$ and supplemented with $1 \mathrm{~mm}$ of the calcium chelator EGTA). D1mediated PKA activity appeared to be undisturbed in the $\mathrm{Ca}^{2+}$-free buffer, as SKF38393 induced a pronounced Ser ${ }^{845}$ phosphorylation of GluA1 (Fig. 4A, left; SKF: $365.2 \pm 63.58 \%$ of untreated control, $p<0.05, n=4-6)$. However, under these conditions, SKF38393 did not induce ERK1/2 phosphorylation in the DA-denervated striatum (Fig. 4A, right; SKF: $101.7 \pm$ $9.20 \%$ of untreated control, $p>0.05, n=4-6$ ). Thus, although PKA activation through D1R does not depend on $\mathrm{Ca}^{2+}$ influx, ERK1/2 activation downstream of PKA indeed does.

Calcium ions have two major entryways into SPNs: NMDA receptors and voltage-gated $\mathrm{Ca}^{2+}$ channels (VGCCs). The $\mathrm{Ca}^{2+}$ dependence of SKF-induced ERK1/2 phosphorylation indicates that, at one point in the signaling cascade, one of these two entryways may be involved. Having excluded a role for NMDA receptors (Fig. 3), we next addressed the involvement of VGCCs. Among the VGCCs, L-type calcium channels have the largest conductance and slowest inactivation kinetics (Tsien et al., 1988), so we targeted these using their antagonist, isradipine $(10 \mu \mathrm{M})$. This compound completely prevented the SKF38393-induced increase in ERK1/2 phosphorylation (Fig. 4C; SKF+Isra: $121.9 \pm$ $7.88 \%$ of untreated control, $p<0.05$ vs SKF alone).

Evidence has accumulated that nonreceptor tyrosine kinases can link G-protein coupled receptor signaling to MAPK activation in a Ca ${ }^{2+}$-dependent manner (Nagao et al., 1998; Pierce et al., 2001). Src family kinases can be involved in $\mathrm{Ca}^{2+}$-triggered ERK1/2-activation (Perkinton et al., 1999; Hu et al., 2009) and have recently emerged as potential mediators of cocaine- and DA-induced ERK1/2-phosphorylation in striatal SPNs both in vivo and in culture preparations (Fiorentini et al., 2011; Nishi et al., 2011; Pascoli et al., 2011). To investigate the potential involvement of Src kinases in D1R-mediated ERK1/2 activation, slices from DA-denervated rats were incubated with the selective Src kinase inhibitor PP-2 $(10 \mu \mathrm{M})$ before applying SKF38393. The Src inhibitor completely prevented the D1R-mediated ERK1/2 phosphorylation (Fig. $4 C$; SKF + PP-2: $58.5 \pm 13.56 \%$ of untreated control, $p<0.001$ vs SKF alone, $p>0.05$ vs untreated control, $n=6-12)$.

\section{Antagonizing mGluR5 signaling interferes with D1R-mediated ERK1/2 phosphorylation}

Systemic treatment with the selective mGluR5 antagonist MTEP has been found to blunt L-DOPA-induced striatal ERK1/2 activation in unilaterally 6-OHDA-lesioned rats (Rylander et al., 2009). In line with these observations, slice application of MTEP $(10 \mu \mathrm{M})$ attenuated the SKF38393-induced increase in phosphoERK1/2 levels by $>50 \%$ (Fig. $5 A$; SKF+MTEP $149.9 \pm 14.63 \%$ of untreated control, $p<0.01$ vs SKF alone). By contrast, levels of Ser ${ }^{845}$-GluA1 phosphorylation were unaffected by MTEP (Fig. 


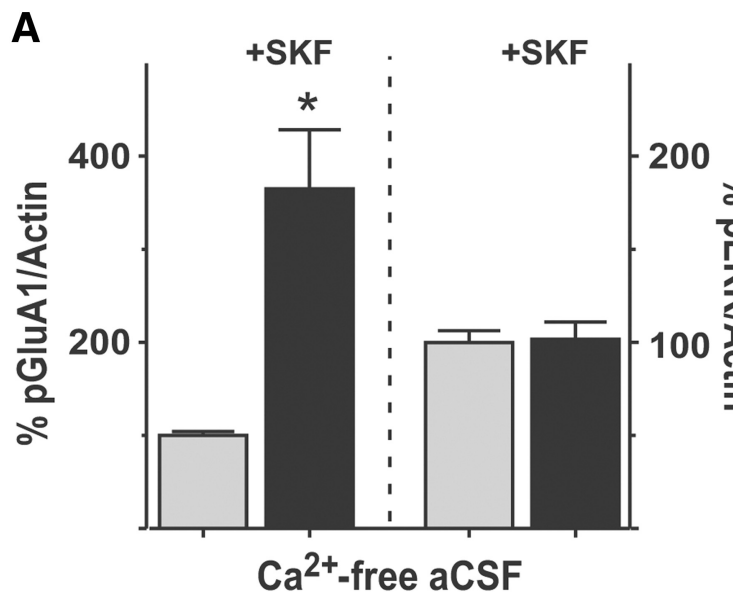

B

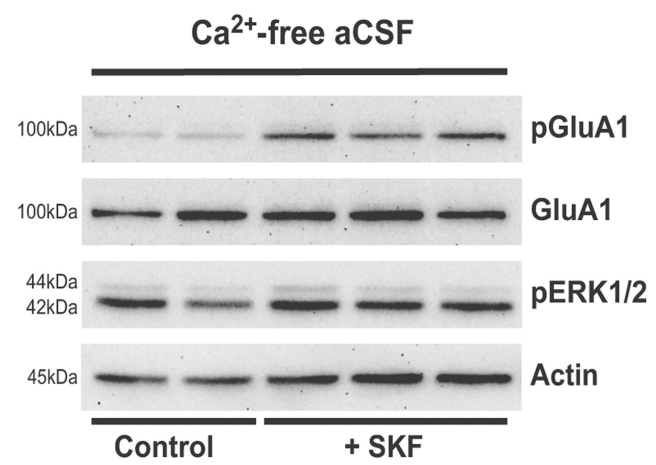

C

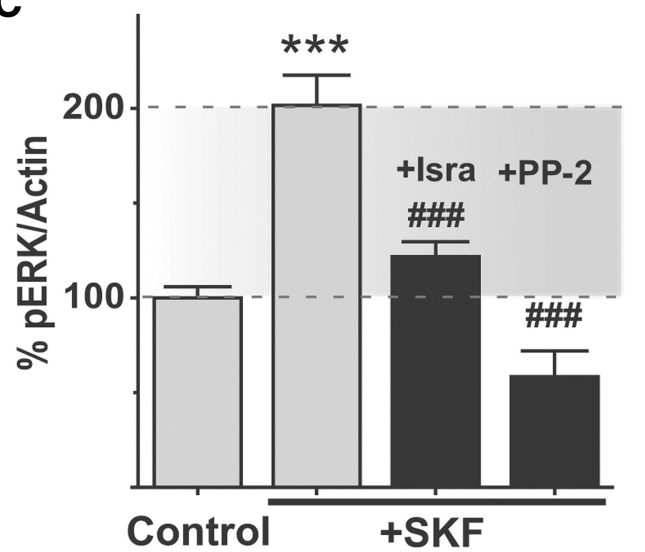

Figure 4. SKF38393-induced ERK1/2 phosphorylation in the DA-denervated striatum depends on $\mathrm{Ca}^{2+}$ influx through calcium channels and on Src family kinases. $A, B$, Removing $\mathrm{Ca}^{2+}$ from the external buffer occludes ERK1/2 phosphorylation by SKF38393. In $\mathrm{Ca}^{2+}$-free aCSF, SKF38393 induces PKA-dependent phosphorylation of GluA1, but not phosphorylation of ERK1/2, showing that extracellular $\mathrm{Ca}^{2+}{ }^{2+}$ is necessary for ERK1/2 induction $(A) .{ }^{*} p<0.05$ (unpaired Student'sttest). $n=4-6$. Representative blots of these experiments are shown in $\boldsymbol{B}$. C, Blocking L-type calcium channels with isradipine or inhibiting Src kinases with PP-2 prevents D1R-induced ERK1/2 phosphorylation (C). ${ }^{* * *} p<0.001$ versus untreated control (Bonferroni's multiple comparison test).\#\# $p<0.001$ versus SKF treatment (Bonferroni's multiple comparison test). $n=6-12$.

5B; SKF+MTEP: $463.4 \pm 37.29 \%$ of untreated control, $p>0.05$ vs SKF alone).

We next addressed the involvement of signaling mediators downstream of mGluR5. Through its coupling to $G_{q}$ mGluR5 activates phospholipase C (PLC), which in turn catalyzes the cleavage of phosphatidylinositol-4,5-bisphosphate to inositol trisphosphate $\left(\mathrm{IP}_{3}\right)$ and diacylglycerol. The latter activates protein kinase $\mathrm{C}(\mathrm{PKC})$ in the presence of $\mathrm{Ca}^{2+}$ (Pin and Duvoisin,
A

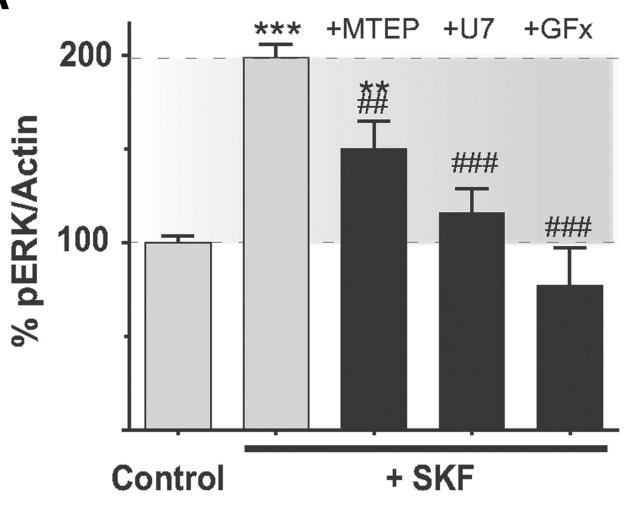

B

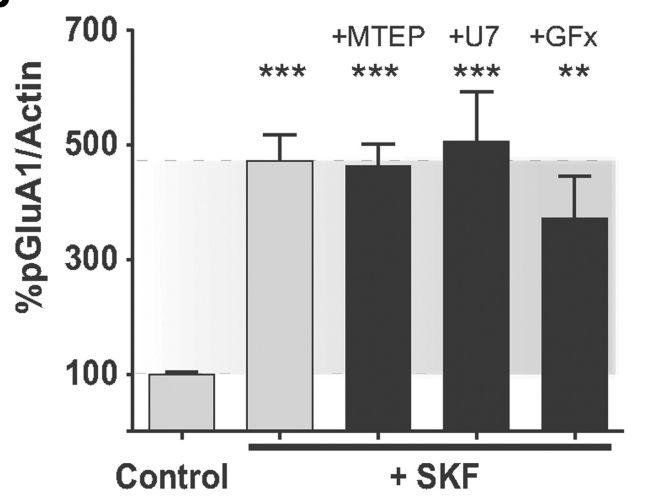

C

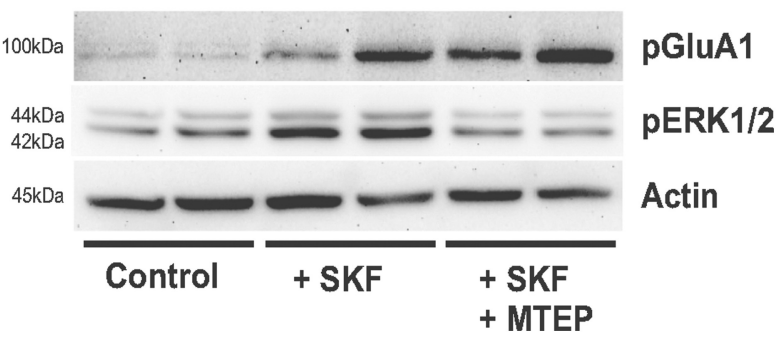

Figure 5. mGluR5 and related intracellular signaling pathways are involved in SKF38393induced ERK1/2 phosphorylation in the DA-denervated striatum. $A$, Antagonizing mGluR5 (MTEP) or its downstream effectors PLC (U73122, "U7") and PKC (GF109203X, "GFx") inhibits D1R-induced ERK1/2 phosphorylation in the DA-denervated striatum. ${ }^{* *} p<0.01$ versus untreated control (Bonferroni's Multiple Comparison test). ${ }^{* * *} p<0.001$ versus untreated control (Bonferroni's Multiple Comparison test). ${ }^{\# \#} p<0.01$ versus SKF treatment (Bonferroni's Multiple Comparison test). ${ }^{\# \#} p<0.001$ versus SKF treatment (Bonferroni's Multiple Comparison test). $n=6-20 . B$, This effect, however, is not the result of an inhibition of PKA activity, as SKF38393-induced Ser ${ }^{845}$ phosphorylation of GluA1 is not affected by the above treatments. ${ }^{* * *} p<0.001$ versus untreated controls (Bonferroni's Multiple Comparison test). ${ }^{* *} p<0.01$ versus untreated controls (Bonferroni's Multiple Comparison test). $n=6-20$. Representative blots showing the effect of MTEP on SKF38393-induced ERK1/2- and GluA1-phosphorylation are shown in $\boldsymbol{C}$.

1995). To inhibit PLC or PKC, slices were incubated with U73122 $(7.5 \mu \mathrm{M})$ or GF109203× $(1 \mu \mathrm{M})$, respectively. Each of these antagonists completely prevented the SKF38393-induced increase in phospho-ERK1/2 levels (Fig. 5A; SKF+U73122: $115.9 \pm$ $12.78 \%$ and SKF+GFx: $77.19 \pm 20.02 \%$ of untreated controls, $p<0.05$ vs SFK alone and $p>0.05$ vs untreated controls, $n=$ $6-20$ ). Like MTEP, the PLC and PKC antagonists did not significantly alter the D1R agonist-induced phosphorylation of Ser ${ }^{845}$ GluA1 (Fig. 5B; SKF+U73122: $507.0 \pm 85.74 \%$ and SKF+GFx: 
A

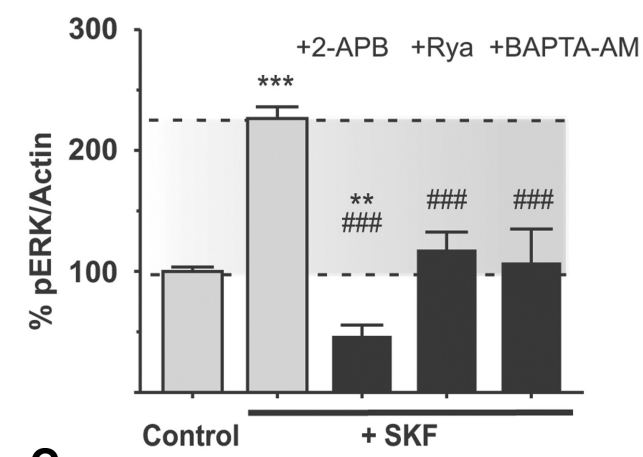

C

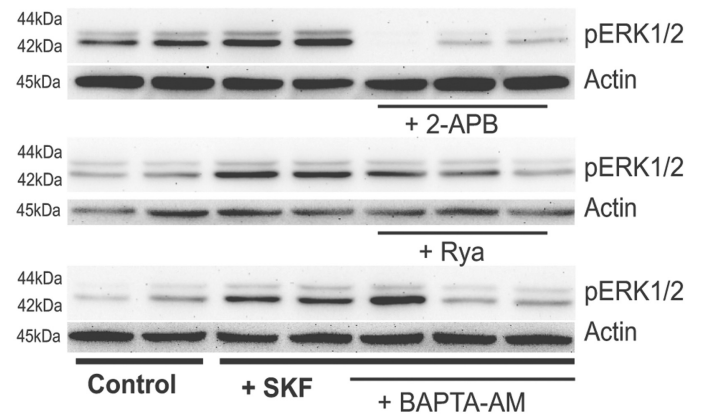

Figure 6. Release of calcium from intracellular stores is important for ERK1/2 activation. $\boldsymbol{A}-\boldsymbol{C}$, Release of Ca ${ }^{2+}$ from internal stores is important for SKF38393-induced ERK1/2 phosphorylation as the effect of the D1R-agonist is prevented by pharmacological antagonists of $\mathrm{IP}_{3}$ receptors (2-APB), ryanodine receptors (ryanodine, "Rya"), or chelating intracellular $\mathrm{Ca}^{2+}$ with BAPTA-AM $(\boldsymbol{A}) .{ }^{* *} p<0.01$ (Bonferroni's Multiple Comparison test). ${ }^{* * *} p<0.001$ versus untreated control (Bonferroni's Multiple Comparison test). ${ }^{\# \# \#} p<0.001$ versus SKF treatment alone (Bonferroni's Multiple Comparison test). $n=4-15$. Representative blots of these treatments are shown in $\boldsymbol{C}$. Effects of the above treatments when applied in the absence of SKF38393 stimulation are shown in $\boldsymbol{B}$. All these treatments reduced baseline levels of phospho-ERK1/2 $(\boldsymbol{B}){ }^{* * *} p<0.001$ versus untreated control (Bonferroni's Multiple Comparison test). $n=7-25$.

$372.3 \pm 73.11 \%$ of untreated controls; $p>0.05$ vs SKF alone, $p<$ $0.001 / p<0.01$ vs untreated controls, $n=9-18$ ).

mGluR5 regulates $\mathrm{Ca}^{2+}$ release from the endoplasmic reticulum via PLC-mediated production of $\mathrm{IP}_{3}$ and ensuing stimulation of $\mathrm{IP}_{3}$ receptors (Pin and Duvoisin, 1995). Binding of $\mathrm{IP}_{3}$ to $\mathrm{IP}_{3}$ receptors releases $\mathrm{Ca}^{2+}$, which in turn can trigger additional release from nearby $\mathrm{IP}_{3}$ and ryanodine receptors, a process termed calcium-induced calcium release (Berridge, 1998; Clements et al., 2013). We addressed the potential involvement of $\mathrm{IP}_{3}$ - and ryanodine receptors in SKF-induced ERK1/2 activation using selective antagonists. Slices from DA-denervated rats were preincubated with the membrane-permeable $\mathrm{IP}_{3}$ receptor antagonist $2-\mathrm{APB}(50 \mu \mathrm{M})$ or with ryanodine $(10 \mu \mathrm{M})$. These treatments completely prevented SKF38393-induced ERK1/2 activation (Fig. $6 A$; SKF+2-APB: $46.70 \pm 8.98 \%$ and SKF+Rya: $118.00 \pm 14.49 \%$ of untreated control, $p<0.001$ vs SKF alone, $n=9-15)$. However, both treatments also reduced basal levels of phospho-ERK1/2 in the slices (Fig. 6B; 2-APB alone: $61.57 \pm 10.17 \%$ of controls; ryanodine alone: $50.93 \pm$ $7.56 \%$ of controls, $p<0.05$ vs untreated controls, $n=4-6$ ). To further verify the importance of intracellular $\mathrm{Ca}^{2+}$ signaling, DAdenervated slices were treated with the membrane permeable $\mathrm{Ca}^{2+}$ chelator BAPTA-AM $(20 \mu \mathrm{M})$, which rapidly buffers any change in intracellular calcium concentration. This treatment abolished the SKF-induced increase in ERK1/2 phosphorylation (Fig. $6 A$; SKF+BAPTA-AM: $107.40 \pm 27.61 \%$ of untreated control, $p<0.001$ vs SKF alone, $n=4-15$ ), although it also reduced baseline levels of phospho-ERK1/2 (Fig. 6B; BAPTA-AM: $39.11 \pm 4.77 \%, p<0.05$ vs untreated controls).
In vivo confirmation of a D1R-mGluR5 crosstalk in

\section{ERK1/2 activation}

Systemically administered mGluR5 antagonists have been shown to attenuate L-DOPA-induced ERK1/2 activation in hemiparkinsonian animals (Rylander et al., 2009). However, where and how this effect is achieved have thus far remained unknown. Our ex vivo data suggest that the effect of MTEP on D1R-mediated ERK1/2 signaling is mediated postsynaptically on striatal SPNs. We tested this hypothesis by intrastriatal drug delivery via reverse microdialysis in the DA-denervated striatum of 6-OHDA-lesioned rats. On the day of the experiment, animals were first infused with MTEP (1 mM, $60 \mathrm{~min}$ ) or Ringer's solution and then challenged with a single subcutaneous injection of $1.5 \mathrm{mg} / \mathrm{kg}$ SKF38393, a dose sufficient to induce immediate early gene expression (Fiorentini et al., 2013) and dyskinetic behaviors in this animal model of PD (Iderberg et al., 2013). The animals were perfused $30 \mathrm{~min}$ after injection, and ERK1/2 phosphorylation was assessed by immunohistochemistry. In vehicle-treated animals, SKF38393 produced a widespread and marked activation of phospho-ERK1/2 immunoreactivity in the DA-denervated striatum (Fig. $7 A, B$ ). Animals infused with MTEP showed a significantly reduced number of phospho-ERK1/2-positive cells in the lateral striatum, this reduction being particularly striking in the ventrolateral quadrant (Fig. 7C; $p<0.05$ for MTEP vs Ringer infusion in both dorsolateral and ventrolateral striatum). The induction of phospho-ERK $1 / 2$ by SKF was however unaffected by MTEP in the dorsomedial striatum (Fig. 7B, bottom, $C$ ).

To verify whether MTEP also had affected signaling responses downstream of phospho-ERK1/2, adjacent sections were immunostained for phospho-Ser ${ }^{10}$-histone-H3 (phospho-H3), which is an important nuclear target of ERK1/2 in rodent models of LID (Santini et al., 2009; Alcacer et al., 2012). Treatment with SKF induced a large number of phospho-H3-immunoreactive cells throughout the DA-denervated striatum in rats infused with Ringer (Fig. $7 D, E)$. Intrastriatal infusion of MTEP greatly attenuated the effect of SKF in the lateral striatum (Fig. 7F; $p<0.05$ for MTEP vs Ringer in both dorsolateral and ventrolateral striatum). However, the SKF-induced phospho-H3 expression was unaffected by MTEP in the dorsomedial striatum (Fig. 7E, bottom, F). Together, these results show that local mGluR5 antagonism directly counteracts D1R agonist-induced ERK1/2 phosphorylation in the lateral, but not the medial, part of the DA-denervated striatum. To exclude that this regional pattern depended on differences in MTEP concentrations within the striatum, we verified the results using a complementary approach.

To this end, unilateral 6-OHDA lesions were applied to transgenic mice with selective knockdown of mGluR5 in D1R-expressing neurons $\left(m G l u R 5^{K D-D 1}\right)$. These mice were estimated to have at least $90 \%$ reduction of mGluR5 mRNA in D1R-expressing SPNs (Novak et al., 2010). In nontransgenic 6-OHDA-lesioned littermates, a single dose of SKF38393 (3 mg/kg, i.p.) induced ERK1/2 
phosphorylation throughout the DAdenervated striatum (Fig. $8 A$, left column). In 6-OHDA-lesioned $m G l u R 5^{K D-D 1}$ mice, this effect was attenuated in a region-specific manner (Fig. 8A, right column). The number of phospho-ERK1/2-positive cells was significantly reduced in the dorsolateral and ventrolateral striatum (Fig. $8 A$, top and middle row; $p<0.05$ vs same ROIs in nontransgenic littermates) but unaffected in the dorsomedial quadrant (Fig. $8 A$, bottom row; Fig. $8 B$ ). Paralleling these changes, the SKF38393-induced phospho-H3 immunoreactivity was significantly reduced in $m G l u R 5^{K D-D 1}$ mice in the dorsolateral and ventrolateral striatum (Fig. $8 C$; $p<$ 0.05 vs same ROIs in nontransgenic littermates) while being unaffected in the dorsomedial region (Fig. $8 C ; p>0.05$ vs nontransgenic littermates).

In summary, the in vivo data confirm our ex vivo findings that mGluR5 has a key role in the modulation of D1R-dependent ERK1/2 signaling in the DA-denervated striatum, at least the portion of this structure where dyskinesia-associated gene expression changes are most pronounced (Andersson et al., 1999).

\section{Discussion}

In animal models of $\mathrm{PD}$, a large activation of ERK1/2 signaling downstream of D1 receptors is the hallmark of a molecular reorganization that is critical to the development of L-DOPA-induced dyskinesia (Westin et al., 2007; Darmopil et al., 2009; Santini et al., 2009; Cenci and Konradi, 2010; Alcacer et al., 2012; Fiorentini et al., 2013). Treatments reducing D1R-mediated/ L-DOPA-induced ERK1/2 phosphorylation consistently improve dyskinesia in rodent and nonhuman primate models of LID (Schuster et al., 2008; Rylander et al., 2009; Fasano et al., 2010; Marti et al., 2013). Among antidyskinetic treatments that are now under clinical development, antagonists of mGluR5 reduce L-DOPAinduced ERK1/2 activation in the striatum (Rylander et al., 2009), but the mechanisms underlying this effect have remained unknown.

In this study, we have investigated signaling pathways mediating D1R agonistinduced ERK1/2 activation in acute brain slices from 6-OHDA-lesioned animals. At a concentration sufficient to induce PKAmediated responses in both intact and DA-denervated slices, SKF38393 activated ERK1/2 signaling only in the latter preparation. The activation of ERK $1 / 2$ in DA-denervated slices was not associated with an increase in glutamatergic synaptic
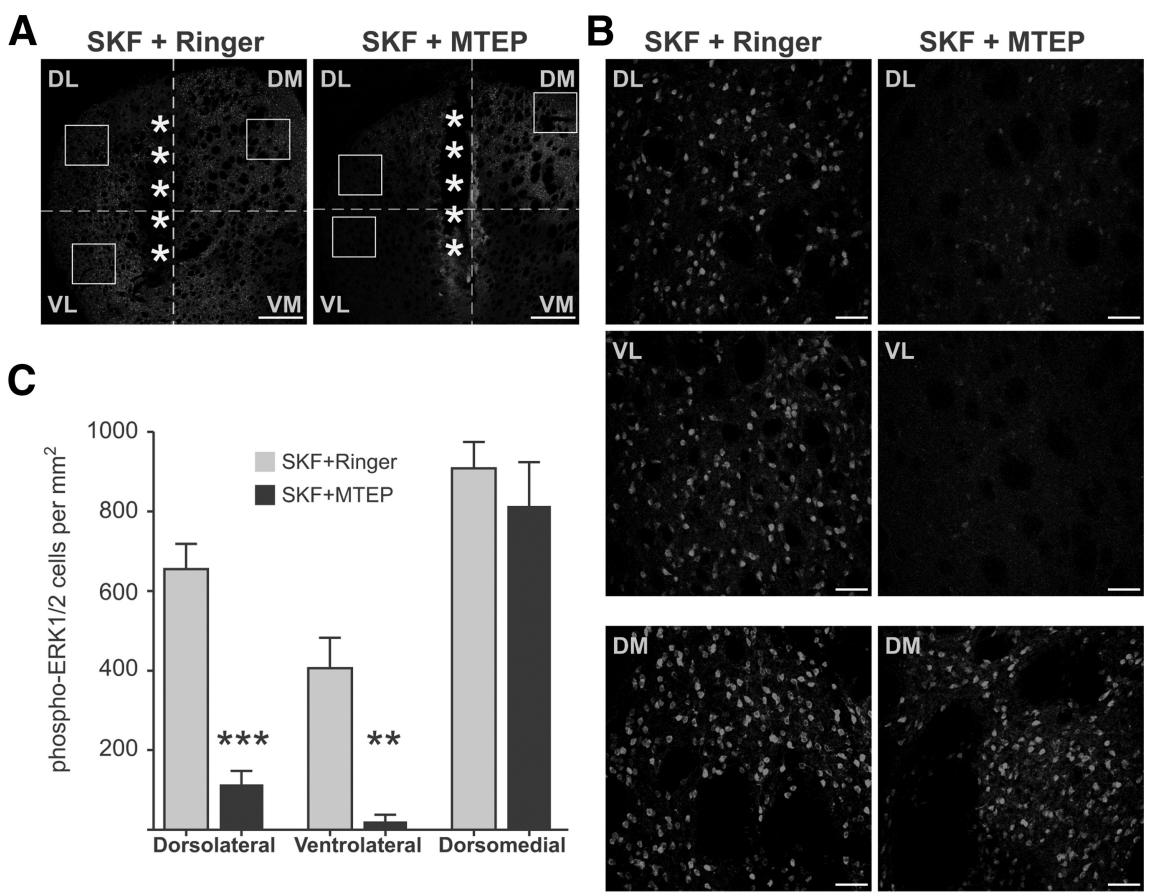

\section{D}

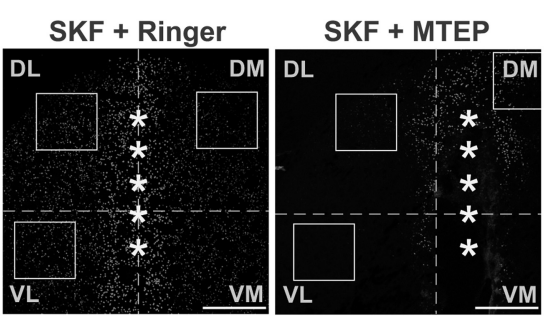

E SKF + Ringer
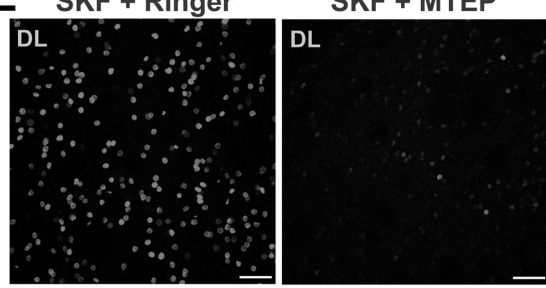

$\mathbf{F}$
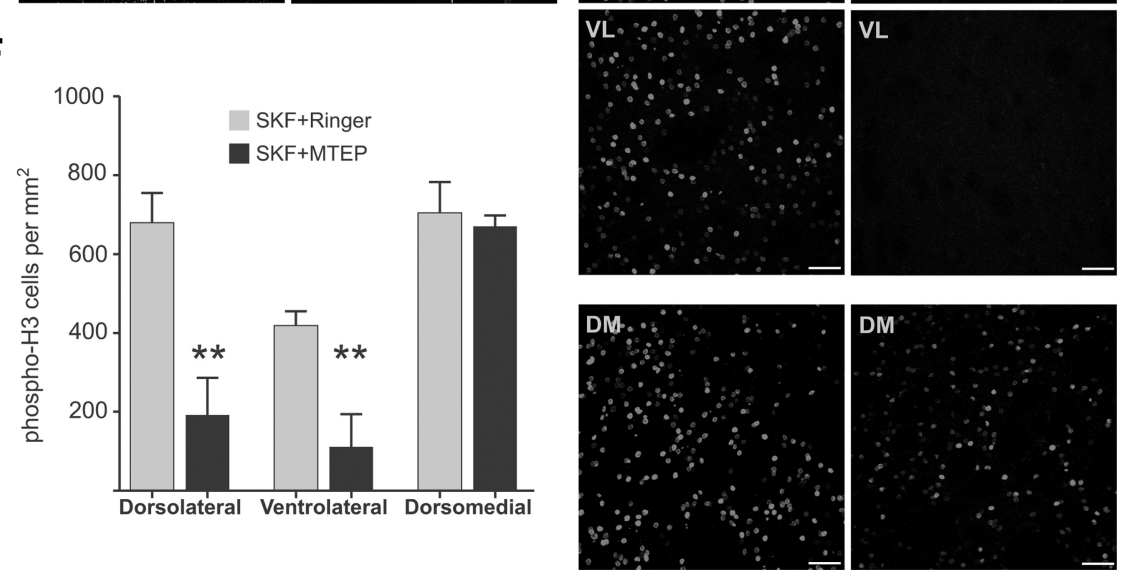

Figure 7. Intrastriatal infusion of MTEP in 6-OHDA-lesioned rats modulates SKF38393-induced ERK1/2 signaling activation. A-C, Systemic injection of the D1-like agonist SKF38393 induces strong activation of phospho-ERK1/2 in the DAdenervated striatum of 6-OHDA-lesioned rats $(\boldsymbol{A}$, left), which is reduced by intrastriatal infusion of the mGluR5-antagonist $\operatorname{MTEP}(\boldsymbol{A}$, right). Boxes represent the three ROls (dorsolateral, ventrolateral, and dorsomedial striatum) used for quantitative analysis, which are represented at higher magnification in $\boldsymbol{B}$. MTEP significantly reduced the number of phosphoERK1/2-positive cells in the dorsolateral and ventrolateral striatum ( $\boldsymbol{B}$, top and middle), while having no effect in the dorsomedial striatum ( $\boldsymbol{B}$, bottom). The results of automated cell counts are shown in $\boldsymbol{C} .{ }^{* *} p<0.01$ versus the same region in vehicle-infused animals (unpaired Student's $t$ test). ${ }^{* *} p<0.001$ versus the same region in vehicle-infused animals (unpaired Student's $t$ test). $n=5$ or 6 animals per group. $\boldsymbol{D}-\boldsymbol{F}$, Systemic treatment with SKF38393 also induced phosphorylation of histone $\mathrm{H} 3$ in the DA-denervated striatum ( $\boldsymbol{D}$, left), which was significantly reduced by MTEP ( $\boldsymbol{D}$, right). The effect of MTEP was significant in the dorsolateral and ventrolateral striatum ( $\boldsymbol{E}$, top and middle), but not in the dorsomedial striatum ( $\boldsymbol{E}$, bottom). The results of automated cell counts are shown in $\boldsymbol{F}^{* *} p<0.01$ versus the same region in vehicleinfused animals (unpaired Student's $t$ test). $n=5$ or 6 animals per group. Scale bars: $\boldsymbol{A}, \boldsymbol{D}, 500 \mu \mathrm{m} ; \boldsymbol{B}, \boldsymbol{E}, 50 \mu \mathrm{m} . \boldsymbol{A}, \boldsymbol{D}$, *Location of the microdialysis probe. The area of damaged tissue surrounding the probe track showed some unspecific staining and was always excluded from quantitative analysis. 


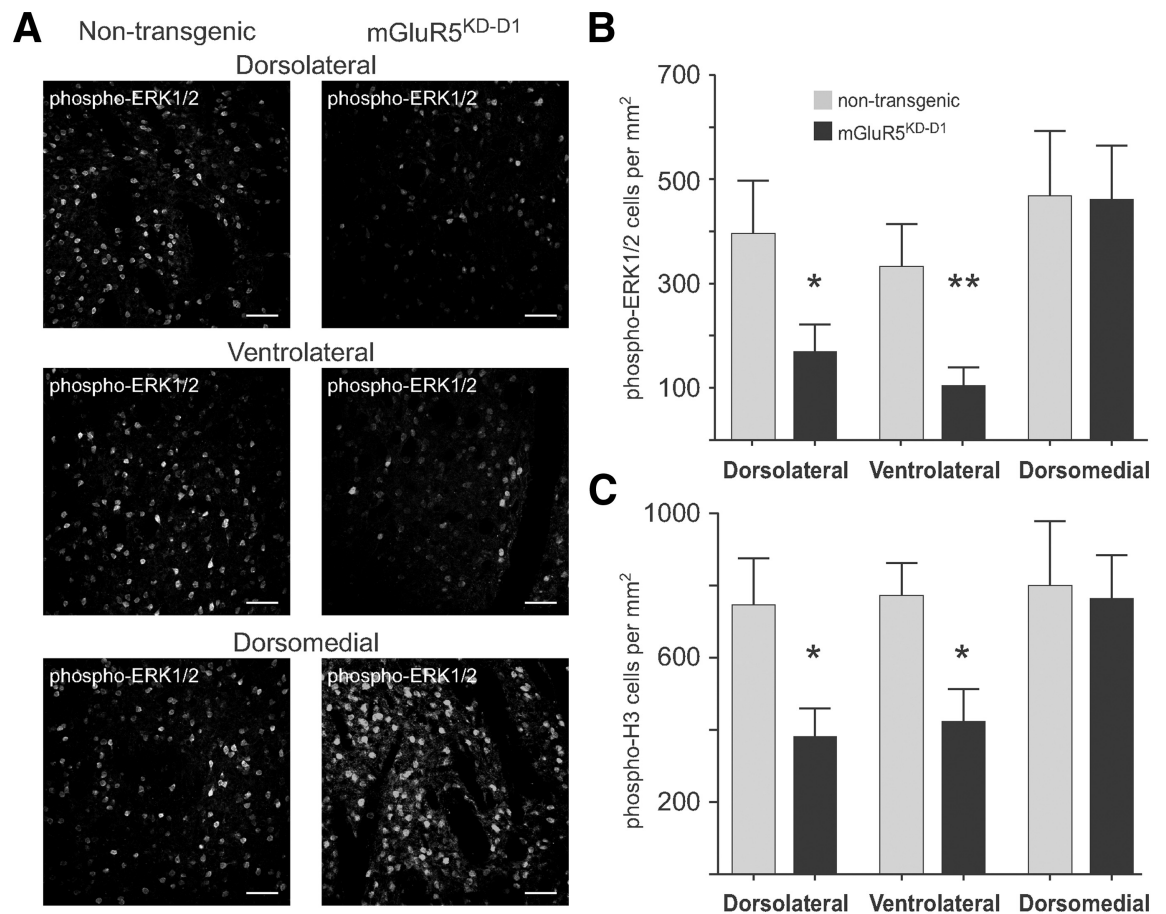

Figure 8. Specific knockdown of mGluR5 in D1R-expressing neurons reduces striatal ERK1/2-signaling activation by SKF38393. $A, B$, Systemic injection of SKF38393 induces significant ERK1/2 phosphorylation in the DA-denervated striatum of nontransgenic mice with unilateral 6-OHDA lesions ( $\boldsymbol{A}$, left column). ERK1/2 activation is reduced in mice with cell-specific knockdown of mGluR5 in D1R-expressing neurons ( $m G$ luR $\left.5^{K D-D 1}\right)(\boldsymbol{A}$, right column). The difference between genotypes was significant in the dorsolateral and ventrolateral regions, but not in the dorsomedial striatum $(\boldsymbol{B}) .{ }^{*} p<0.05$ versus the same region in nontransgenic animals (unpaired Student's $t$ test). ${ }^{* *} p<0.01$ versus the same region in nontransgenic animals (unpaired Student's $t$ test). $n=8-13$ animals per group. C, Phosphorylation of histone H3 (downstream target of ERK1/2) is also significantly reduced in the dorsolateral and ventrolateral striatum of $m G l u R S^{K D-D 1}$ mice. ${ }^{*} p<0.05$ versus the same region in nontransgenic animals (unpaired Student's $t$ test). $n=8-13$ animals per group. Scale bar: $\boldsymbol{A}, 50 \mu \mathrm{m}$.

transmission and did not require NMDA receptor activity. This signaling response was however significantly reduced by MTEP, a selective negative allosteric modulator of mGluR5. The same compound did not attenuate the SKF-induced phosphorylation of Ser ${ }^{845}$-GluA1. These data indicate that, in DA-denervated striata, SKF-induced ERK1/2 activation relies on a functional interaction between D1R- and mGluR5-dependent signaling occurring downstream of PKA. It requires PLC, PKC, and Src kinases, as indicated by the dramatic effects of the corresponding antagonists in blocking SKF-induced increases in phosphoERK1/2 levels. The mGluR5 is a major regulator of intracellular calcium dynamics via both stimulation of $\mathrm{IP}_{3}$ production and modulation of L-type VGCC activity (see below). In slices incubated with antagonists of L-type VGCC, $\mathrm{IP}_{3}$ receptors, ryanodine receptors, or with a chelator of intracellular calcium, SKF38393 did not induce any ERK1/2 activation. Although some of the above treatments also reduced the basal levels of phosphoERK1/2, at least the effect of the $\mathrm{IP}_{3}$ antagonist (2-APB) was very clear and phospho-ERK1/2 levels were virtually the same in slices incubated with the antagonist alone or combined with SKF38393.

Striatal slices represent a well-established ex vivo model to study direct effects of signaling modulators on mature striatal neurons, but they may not completely reflect the situation in vivo. In particular, the striatal inducibility of phospho-ERK1/2 in vivo is conditioned by the activities of glutamatergic and monoaminergic afferents projecting to a specific region (Gangarossa et al., 2013). We therefore set out to verify our hypothesis of a D1R-mGluR5 signaling crosstalk in the DA-denervated striatum using 6-OHDA-lesioned animals treated systemically with SKF38393. Local infusion of MTEP in the DA-denervated rat striatum strongly attenuated the activation of ERK1/2 signaling by SKF38393. Furthermore, 6-OHDA-lesioned transgenic mice with a cell-specific knockdown of mGluR5 in D1R-expressing neurons showed a blunted striatal ERK1/2 activation in response to SFK38393 treatment. In both experimental models, mGluR5 inhibition had a significant effect in the lateral part of the striatum, whereas SKF-induced phosphoERK1/2 remained unaltered in the dorsomedial quadrant. This regional specificity is unlikely to depend on potential differences in mGluR5 abundance across striatal quadrants (Testa et al., 1994, 1995). Because DA agonist-induced striatal ERK1/2 activation in intact mice shows region-specific patterns, matching the cortical and thalamic inputs to each region (Gangarossa et al., 2013), the differential role of mGluR5 in the medial versus lateral striatum observed in this study is likely to depend on the anatomofunctional properties of these regions. The lateral striatum processes sensorimotor information (McGeorge and Faull, 1989), shows low basal ERK1/2 activity and low ERK1/2 inducibility by DA agonists in intact animals (Gangarossa et al., 2013), but exhibits very pronounced ERK1/2 activation and gene expression changes in L-DOPAtreated dyskinetic animals (Andersson et al., 1999; Westin et al., 2007). This region is also particularly crucial to the generation of dyskinetic behaviors, as indicated by the effects of local molecular or neurochemical manipulations (Andersson et al., 1999, 2001; Carta et al., 2006).

Together, our results provide the first demonstration that locally expressed mGluR5 participates in the signaling cascade through which D1R stimulation leads to ERK1/2 activation in DA-denervated neurons in the sensorimotor part of the striatum.

\section{Different routes to ERK1/2 activation in the DA-denervated versus the intact striatum}

Drugs of abuse have been shown to induce striatal ERK1/2 phosphorylation through NMDA receptors and DARPP-32 (Valjent et al., 2005; Pascoli et al., 2011). However, NMDA receptors antagonists do not block D1R-mediated ERK1/2 phosphorylation in a DA-denervated striatum (Gerfen et al., 2002; Rylander et al., 2009), and conflicting data have been published regarding the involvement of DARPP-32 in this response (Gerfen et al., 2008; Santini et al., 2012). Our findings from DA-denervated slices confirm that D1R agonist-induced ERK1/2 activation is independent of NMDA receptors, being in line with in vivo data from 6-OHDA-lesioned rats (Gerfen et al., 2002; Rylander et al., 2009). One can thus conclude that D1R-mediated ERK1/2 activation in the parkinsonian striatum does not follow the same NMDARdependent route that is recruited by drugs of abuse in intact animals (Valjent et al., 2005; Nishi et al., 2011; Pascoli et al., 2011). Even though $\mathrm{Ca}^{2+}$ influx appears necessary to induce ERK1/2 phosphorylation in both forms of drug-induced plastic- 
ity, L-type VGCCs, not NMDA receptors, are the most likely mediators of this influx in the DA-denervated striatum.

\section{Signaling responses regulated by $\mathrm{mGluR} 5$ and leading to ERK1/2 activation}

Ultrastructural investigations of striatal SPNs have shown that mGluR5 tends to accumulate at the border between postsynaptic and perisynaptic membranes (Uchigashima et al., 2007). L-type VGCCs are also present in this region (Olson et al., 2005), and their function in striatal neurons is modulated by DA-activated PKA (Surmeier et al., 1995). In addition to being physically close on the plasma membrane, mGluR5 and L-type VGCC are anchored to the same scaffolding complex, connected to intracellular $\mathrm{IP}_{3}$ and ryanodine receptors (Olson et al., 2005; Xiao et al., 2000; Sala et al., 2005; Chavis et al., 1996). A cooperative action between $\mathrm{Ca}^{2+}$ influx via L-type VGCC and mGluR5-dependent modulation of intracellular $\mathrm{Ca}^{2+}$ dynamics is further crucial to certain forms of synaptic plasticity (Kato et al., 2012; Lerner and Kreitzer, 2012). Our results suggest that similar $\mathrm{Ca}^{2+}$-dependent processes are also involved in D1R agonist-induced ERK1/2 activation in a DA-denervated striatum. In line with the membrane relocalization of D1R observed in the DA-denervated striatum (Fiorentini et al., 2006), one can speculate that a close biophysical proximity between D1R and mGluR5 may lead to the formation of new signaling complexes. Such a process may account, at least in part, for the strong interactions between D1R- and mGluR5related signaling presented in this study. Alternatively, one may speculate that mGluR5 is required to maintain a "permissive" tone of PLC-mediated signaling that allows D1R agonists to activate ERK1/2 in the DA-denervated striatum. Supporting this interpretation, a recent study suggests that PLC mediates some of the effects of D1R activation in the striatum (Medvedev et al., 2013), although there is no evidence that bona fide D1R can directly couple to a $\mathrm{G}_{\mathrm{q}}-\mathrm{PLC}$ pathway in native striatal tissue (for review, see Undieh, 2010).

Nonreceptor tyrosine kinases of the Src family may provide a link between many of the signaling components that are involved in SKF-induced ERK1/2 activation. Previous work has indicated that Src kinases can mediate D1R- and NMDAR-dependent ERK1/2 activation in striatal neurons (Mao et al., 2009; Fiorentini et al., 2011; Nishi et al., 2011). Src kinases are activated downstream of various types of receptors and can act as integrators of PKA and PKC signaling (Salter and Kalia, 2004). In turn, Src kinases can promote ryanodine receptor-dependent intracellular $\mathrm{Ca}^{2+}$ release in striatal neurons (Fagni et al., 2000; Lerner and Kreitzer, 2012). These nonreceptor tyrosine kinases are therefore in a position to promote ERK1/2 activation in two potential ways: (1) coincidence detection of PKA and PKC activation; and (2) enhancement of intracellular $\mathrm{Ca}^{2+}$ levels through release from ryanodine receptors.

In conclusion, our results suggest that D1R agonist-induced ERK1/2 phosphorylation in the DA-denervated striatum critically depends on a complex interaction between PKA-mediated and calcium-dependent responses, requiring signal integration through Src kinases. Striatal mGluR5 receptors are in a key position to modulate this complex network. Indeed, these $\mathrm{G}_{\mathrm{q}}$ coupled receptors not only exert control over $\mathrm{IP}_{3}$ formation and store-dependent $\mathrm{Ca}^{2+}$ release in striatal SPNs (Clements et al., 2013), but can also modulate L-type VGCC and Src kinases, mostly in a PLC/PKC-dependent fashion (Thandi et al., 2002; Mao et al., 2005; Voulalas et al., 2005; Lerner and Kreitzer, 2012). Our results thus reveal that the mGluR5/PLC/PKC cascade is a potent modulator of D1R agonist-induced ERK1/2 phosphoryla- tion in the DA-denervated striatum without altering D1Rinduced PKA activity. The strong signaling interactions occurring in the DA-denervated striatum between a canonical D1-PKA-mediated pathway and mGluR5/PLC-dependent components are suggestive of profound molecular reorganizations that will need to be unraveled by future studies. These will hopefully inform the development of novel pharmacological therapies for PD.

\section{References}

Alcacer C, Santini E, Valjent E, Gaven F, Girault JA, Hervé D (2012) Galpha(olf) mutation allows parsing the role of cAMP-dependent and extracellular signal-regulated kinase-dependent signaling in L-3,4dihydroxyphenylalanine-induced dyskinesia. J Neurosci 32:59005910. CrossRef Medline

Andersson M, Hilbertson A, Cenci MA (1999) Striatal fosB expression is causally linked with 1-DOPA-induced abnormal involuntary movements and the associated upregulation of striatal prodynorphin mRNA in a rat model of Parkinson's disease. Neurobiol Dis 6:461-474. CrossRef Medline

Andersson M, Konradi C, Cenci MA (2001) cAMP response elementbinding protein is required for dopamine-dependent gene expression in the intact but not the dopamine-denervated striatum. J Neurosci 21: 9930-9943. Medline

Bain J, Plater L, Elliott M, Shpiro N, Hastie CJ, McLauchlan H, Klevernic I, Arthur JS, Alessi DR, Cohen P (2007) The selectivity of protein kinase inhibitors: a further update. Biochem J 408:297-315. CrossRef Medline

Berridge MJ (1998) Neuronal calcium signaling. Neuron 21:13-26. CrossRef Medline

Bhalla US, Iyengar R (1999) Emergent properties of networks of biological signaling pathways. Science 283:381-387. CrossRef Medline

Carta M, Lindgren HS, Lundblad M, Stancampiano R, Fadda F, Cenci MA (2006) Role of striatal L-DOPA in the production of dyskinesia in 6-hydroxydopamine lesioned rats. J Neurochem 96:1718-1727. CrossRef Medline

Cenci MA, Konradi C (2010) Maladaptive striatal plasticity in L-DOPAinduced dyskinesia. Prog Brain Res 183:209-233. CrossRef Medline

Cenci MA, Lundblad M (2007) Ratings of L-DOPA-induced dyskinesia in the unilateral 6-OHDA lesion model of Parkinson's disease in rats and mice. Curr Protoc Neurosci Chapter 9:Unit 9 25. CrossRef Medline

Chavis P, Fagni L, Lansman JB, Bockaert J (1996) Functional coupling between ryanodine receptors and L-type calcium channels in neurons. Nature 382:719-722. CrossRef Medline

Clements MA, Swapna I, Morikawa H (2013) Inositol 1,4,5-triphosphate drives glutamatergic and cholinergic inhibition selectively in spiny projection neurons in the striatum. J Neurosci 33:2697-2708. CrossRef Medline

Darmopil S, Martín AB, De Diego IR, Ares S, Moratalla R (2009) Genetic inactivation of dopamine D1 but not D2 receptors inhibits L-DOPAinduced dyskinesia and histone activation. Biol Psychiatry 66:603-613. CrossRef Medline

Davies SP, Reddy H, Caivano M, Cohen P (2000) Specificity and mechanism of action of some commonly used protein kinase inhibitors. Biochem J 351:95-105. CrossRef Medline

Egea J, Espinet C, Comella JX (1999) Calcium influx activates extracellularregulated kinase/mitogen-activated protein kinase pathway through a calmodulin-sensitive mechanism in PC12 cells. J Biol Chem 274:75-85. CrossRef Medline

Fagni L, Chavis P, Ango F, Bockaert J (2000) Complex interactions between mGluRs, intracellular $\mathrm{Ca}^{2+}$ stores and ion channels in neurons. Trends Neurosci 23:80-88. CrossRef Medline

Fasano S, D’Antoni A, Orban PC, Valjent E, Putignano E, Vara H, Pizzorusso T, Giustetto M, Yoon B, Soloway P, Maldonado R, Caboche J, Brambilla R (2009) Ras-guanine nucleotide-releasing factor 1 (Ras-GRF1) controls activation of extracellular signal-regulated kinase (ERK) signaling in the striatum and long-term behavioral responses to cocaine. Biol Psychiatry 66:758-768. CrossRef Medline

Fasano S, Bezard E, D’Antoni A, Francardo V, Indrigo M, Qin L, Doveró S, Cerovic M, Cenci MA, Brambilla R (2010) Inhibition of Ras-guanine nucleotide-releasing factor 1 (Ras-GRF1) signaling in the striatum reverts 
motor symptoms associated with L-DOPA-induced dyskinesia. Proc Natl Acad Sci U S A 107:21824-21829. CrossRef Medline

Fiorentini C, Rizzetti MC, Busi C, Bontempi S, Collo G, Spano P, Missale C (2006) Loss of synaptic D1 dopamine/N-methyl-D-aspartate glutamate receptor complexes in L-DOPA-induced dyskinesia in the rat. Mol Pharmacol 69:805-812. CrossRef Medline

Fiorentini C, Mattanza C, Collo G, Savoia P, Spano P, Missale C (2011) The tyrosine phosphatase Shp-2 interacts with the dopamine $\mathrm{D}(1)$ receptor and triggers $\mathrm{D}(1)$ mediated Erk signaling in striatal neurons. J Neurochem 117:253-263. CrossRef Medline

Fiorentini C, Savoia P, Savoldi D, Barbon A, Missale C (2013) Persistent activation of the D1R/Shp-2/Erk1/2 pathway in 1-DOPA-induced dyskinesia in the 6-hydroxy-dopamine rat model of Parkinson's disease. Neurobiol Dis 54:339-348. CrossRef Medline

Francardo V, Recchia A, Popovic N, Andersson D, Nissbrandt H, Cenci MA (2011) Impact of the lesion procedure on the profiles of motor impairment and molecular responsiveness to L-DOPA in the 6-hydroxydopamine mouse model of Parkinson's disease. Neurobiol Dis 42:327-340. CrossRef Medline

Gangarossa G, Perroy J, Valjent E (2013) Combinatorial topography and cell-type specific regulation of the ERK pathway by dopaminergic agonists in the mouse striatum. Brain Struct Funct 218:405-419. CrossRef Medline

Gerfen CR, Surmeier DJ (2011) Modulation of striatal projection systems by dopamine. Annu Rev Neurosci 34:441-466. CrossRef Medline

Gerfen CR, Miyachi S, Paletzki R, Brown P (2002) D1 dopamine receptor supersensitivity in the dopamine-depleted striatum results from a switch in the regulation of ERK1/2/MAP kinase. J Neurosci 22:5042-5054. Medline

Gerfen CR, Paletzki R, Worley P (2008) Differences between dorsal and ventral striatum in Drdla dopamine receptor coupling of dopamine- and cAMP-regulated phosphoprotein-32 to activation of extracellular signalregulated kinase. J Neurosci 28:7113-7120. CrossRef Medline

Girault JA (2012) Integrating neurotransmission in striatal medium spiny neurons. Adv Exp Med Biol 970:407-429. CrossRef Medline

Girault JA, Valjent E, Caboche J, Hervé D (2007) ERK2: a logical AND gate critical for drug-induced plasticity? Curr Opin Pharmacol 7:77-85. CrossRef Medline

Hu X, Wu X, Xu J, Zhou J, Han X, Guo J (2009) Src kinase up-regulates the ERK cascade through inactivation of protein phosphatase 2A following cerebral ischemia. BMC Neurosci 10:74. CrossRef Medline

Iderberg H, Rylander D, Bimpisidis Z, Cenci MA (2013) Modulating mGluR5 and 5-HT1A/1B receptors to treat 1-DOPA-induced dyskinesia: effects of combined treatment and possible mechanisms of action. Exp Neurol 250C:116-124. CrossRef Medline

Jiao H, Zhang L, Gao F, Lou D, Zhang J, Xu M (2007) Dopamine D(1) and $\mathrm{D}$ (3) receptors oppositely regulate NMDA- and cocaine-induced MAPK signaling via NMDA receptor phosphorylation. J Neurochem 103:840848. CrossRef Medline

Kato HK, Kassai H, Watabe AM, Aiba A, Manabe T (2012) Functional coupling of the metabotropic glutamate receptor, InsP3 receptor and L-type $\mathrm{Ca}^{2+}$ channel in mouse CA1 pyramidal cells. J Physiol 590:3019-3034. CrossRef Medline

Kocieniewski P, Lipniacki T (2013) MEK1 and MEK2 differentially control the duration and amplitude of the ERK cascade response. Phys Biol 10: 035006. CrossRef Medline

Lebel M, Chagniel L, Bureau G, Cyr M (2010) Striatal inhibition of PKA prevents levodopa-induced behavioural and molecular changes in the hemiparkinsonian rat. Neurobiol Dis 38:59-67. CrossRef Medline

Lee HK, Barbarosie M, Kameyama K, Bear MF, Huganir RL (2000) Regulation of distinct AMPA receptor phosphorylation sites during bidirectional synaptic plasticity. Nature 405:955-959. CrossRef Medline

Lee HK, Takamiya K, Han JS, Man H, Kim CH, Rumbaugh G, Yu S, Ding L, He C, Petralia RS, Wenthold RJ, Gallagher M, Huganir RL (2003) Phosphorylation of the AMPA receptor GluR1 subunit is required for synaptic plasticity and retention of spatial memory. Cell 112:631-643. CrossRef Medline

Lerner TN, Kreitzer AC (2012) RGS4 is required for dopaminergic control of striatal LTD and susceptibility to parkinsonian motor deficits. Neuron 73:347-359. CrossRef Medline

Li Z, Ji G, Neugebauer V (2011) Mitochondrial reactive oxygen species are activated by mGluR5 through IP3 and activate ERK and PKA to increase excitability of amygdala neurons and pain behavior. J Neurosci 31:11141127. CrossRef Medline

Lindgren N, Goiny M, Herrera-Marschitz M, Haycock JW, Hökfelt T, Fisone G (2002) Activation of extracellular signal-regulated kinases 1 and 2 by depolarization stimulates tyrosine hydroxylase phosphorylation and dopamine synthesis in rat brain. Eur J Neurosci 15:769-773. CrossRef Medline

$\mathrm{Lu}$ W, Roche KW (2012) Posttranslational regulation of AMPA receptor trafficking and function. Curr Opin Neurobiol 22:470-479. CrossRef Medline

Manson A, Stirpe P, Schrag A (2012) Levodopa-induced-dyskinesias clinical features, incidence, risk factors, management and impact on quality of life. J Parkinsons Dis 2:189-198. CrossRef Medline

Mao L, Tang Q, Samdani S, Liu Z, Wang JQ (2004) Regulation of MAPK/ ERK phosphorylation via ionotropic glutamate receptors in cultured rat striatal neurons. Eur J Neurosci 19:1207-1216. CrossRef Medline

Mao L, Yang L, Tang Q, Samdani S, Zhang G, Wang JQ (2005) The scaffold protein Homer $1 \mathrm{~b} / \mathrm{c}$ links metabotropic glutamate receptor 5 to extracellular signal-regulated protein kinase cascades in neurons. J Neurosci 25 : 2741-2752. CrossRef Medline

Mao LM, Tang QS, Wang JQ (2009) Regulation of extracellular signalregulated kinase phosphorylation in cultured rat striatal neurons. Brain Res Bull 78:328-334. CrossRef Medline

Marti M, Mela F, Budri M, Volta M, Malfacini D, Molinari S, Zaveri NT, Ronzoni S, Petrillo P, Calò G, Morari M (2013) Acute and chronic antiparkinsonian effects of the novel nociceptin/orphanin FQ receptor antagonist NiK-21273 in comparison with SB-612111. Br J Pharmacol 168: 863-879. CrossRef Medline

Mazzucchelli C, Vantaggiato C, Ciamei A, Fasano S, Pakhotin P, Krezel W, Welzl H, Wolfer DP, Pagès G, Valverde O, Marowsky A, Porrazzo A, Orban PC, Maldonado R, Ehrengruber MU, Cestari V, Lipp HP, Chapman PF, Pouysségur J, Brambilla R (2002) Knockout of ERK1 MAP kinase enhances synaptic plasticity in the striatum and facilitates striatalmediated learning and memory. Neuron 34:807-820. CrossRef Medline

McCoy CE, Campbell DG, Deak M, Bloomberg GB, Arthur JS (2005) MSK1 activity is controlled by multiple phosphorylation sites. Biochem J 387: 507-517. CrossRef Medline

McGeorge AJ, Faull RL (1989) The organization of the projection from the cerebral cortex to the striatum in the rat. Neuroscience 29:503-537. CrossRef Medline

Medvedev IO, Ramsey AJ, Masoud ST, Bermejo MK, Urs N, Sotnikova TD, Beaulieu JM, Gainetdinov RR, Salahpour A (2013) D1 dopamine receptor coupling to PLCbeta regulates forward locomotion in mice. J Neurosci 33:18125-18133. CrossRef Medline

Mulvaney JM, Zhang T, Fewtrell C, Roberson MS (1999) Calcium influx through L-type channels is required for selective activation of extracellular signal-regulated kinase by gonadotropin-releasing hormone. J Biol Chem 274:29796-29804. CrossRef Medline

Nagao M, Yamauchi J, Kaziro Y, Itoh H (1998) Involvement of protein kinase $\mathrm{C}$ and Src family tyrosine kinase in Galphaq/11-induced activation of c-Jun N-terminal kinase and p38 mitogen-activated protein kinase. J Biol Chem 273:22892-22898. CrossRef Medline

Nishi A, Kuroiwa M, Shuto T (2011) Mechanisms for the modulation of dopamine $\mathrm{d}(1)$ receptor signaling in striatal neurons. Front Neuroanat 5:43. CrossRef Medline

Novak M, Halbout B, O'Connor EC, Rodriguez Parkitna J, Su T, Chai M, Crombag HS, Bilbao A, Spanagel R, Stephens DN, Schütz G, Engblom D (2010) Incentive learning underlying cocaine-seeking requires mGluR5 receptors located on dopamine D1 receptor-expressing neurons. J Neurosci 30:11973-11982. CrossRef Medline

Oliveira RF, Kim M, Blackwell KT (2012) Subcellular location of PKA controls striatal plasticity: stochastic simulations in spiny dendrites. PLoS Comput Biol 8:e1002383. CrossRef Medline

Olson PA, Tkatch T, Hernandez-Lopez S, Ulrich S, Ilijic E, Mugnaini E, Zhang H, Bezprozvanny I, Surmeier DJ (2005) G-protein-coupled receptor modulation of striatal $\mathrm{CaV} 1.3 \mathrm{~L}$-type $\mathrm{Ca}^{2+}$ channels is dependent on a Shank-binding domain. J Neurosci 25:1050-1062. CrossRef Medline

Pascoli V, Besnard A, Hervé D, Pagès C, Heck N, Girault JA, Caboche J, Vanhoutte P (2011) Cyclic adenosine monophosphate-independent tyrosine phosphorylation of NR2B mediates cocaine-induced extracellular signal-regulated kinase activation. Biol Psychiatry 69:218-227. CrossRef Medline 
Perkinton MS, Sihra TS, Williams RJ (1999) Ca(2+)-permeable AMPA receptors induce phosphorylation of cAMP response element-binding protein through a phosphatidylinositol 3-kinase-dependent stimulation of the mitogen-activated protein kinase signaling cascade in neurons. J Neurosci 19:5861-5874. Medline

Pierce KL, Luttrell LM, Lefkowitz RJ (2001) New mechanisms in heptaheli$\mathrm{cal}$ receptor signaling to mitogen activated protein kinase cascades. Oncogene 20:1532-1539. CrossRef Medline

Pin JP, Duvoisin R (1995) The metabotropic glutamate receptors: structure and functions. Neuropharmacology 34:1-26. CrossRef Medline

Rosen LB, Ginty DD, Weber MJ, Greenberg ME (1994) Membrane depolarization and calcium influx stimulate MEK and MAP kinase via activation of Ras. Neuron 12:1207-1221. CrossRef Medline

Rylander D, Recchia A, Mela F, Dekundy A, Danysz W, Cenci MA (2009) Pharmacological modulation of glutamate transmission in a rat model of L-DOPA-induced dyskinesia: effects on motor behavior and striatal nuclear signaling. J Pharmacol Exp Ther 330:227-235. CrossRef Medline

Sala C, Roussignol G, Meldolesi J, Fagni L (2005) Key role of the postsynaptic density scaffold proteins Shank and Homer in the functional architecture of $\mathrm{Ca} 2+$ homeostasis at dendritic spines in hippocampal neurons. J Neurosci 25:4587-4592. Medline

Salter MW, Kalia LV (2004) Src kinases: a hub for NMDA receptor regulation. Nat Rev Neurosci 5:317-328. CrossRef Medline

Santini E, Valjent E, Usiello A, Carta M, Borgkvist A, Girault JA, Hervé D, Greengard P, Fisone G (2007) Critical involvement of cAMP/ DARPP-32 and extracellular signal-regulated protein kinase signaling in L-DOPA-induced dyskinesia. J Neurosci 27:6995-7005. CrossRef Medline

Santini E, Alcacer C, Cacciatore S, Heiman M, Hervé D, Greengard P, Girault JA, Valjent E, Fisone G (2009) L-DOPA activates ERK signaling and phosphorylates histone $\mathrm{H} 3$ in the striatonigral medium spiny neurons of hemiparkinsonian mice. J Neurochem 108:621-633. CrossRef Medline

Santini E, Feyder M, Gangarossa G, Bateup HS, Greengard P, Fisone G (2012) Dopamine- and cAMP-regulated phosphoprotein of 32-kDa (DARPP-32)-dependent activation of extracellular signal-regulated kinase (ERK) and mammalian target of rapamycin complex 1 (mTORC1) signaling in experimental parkinsonism. J Biol Chem 287:27806-27812. CrossRef Medline

Schuster S, Nadjar A, Guo JT, Li Q, Ittrich C, Hengerer B, Bezard E (2008) The 3-hydroxy-3-methylglutaryl-CoA reductase inhibitor lovastatin reduces severity of L-DOPA-induced abnormal involuntary movements in experimental Parkinson's disease. J Neurosci 28:4311-4316. CrossRef Medline

Sgambato V, Pagès C, Rogard M, Besson MJ, Caboche J (1998) Extracellular signal-regulated kinase (ERK) controls immediate early gene induction on corticostriatal stimulation. J Neurosci 18:8814-8825. Medline

Shuen JA, Chen M, Gloss B, Calakos N (2008) Drd1a-tdTomato BAC transgenic mice for simultaneous visualization of medium spiny neurons in the direct and indirect pathways of the basal ganglia. J Neurosci 28:26812685. CrossRef Medline

Snyder GL, Allen PB, Fienberg AA, Valle CG, Huganir RL, Nairn AC, Greengard P (2000) Regulation of phosphorylation of the GluR1 AMPA re- ceptor in the neostriatum by dopamine and psychostimulants in vivo. J Neurosci 20:4480-4488. Medline

Surmeier DJ, Bargas J, Hemmings HC Jr, Nairn AC, Greengard P (1995) Modulation of calcium currents by a D1 dopaminergic protein kinase/ phosphatase cascade in rat neostriatal neurons. Neuron 14:385-397. CrossRef Medline

Testa CM, Standaert DG, Young AB, Penney JB Jr (1994) Metabotropic glutamate receptor mRNA expression in the basal ganglia of the rat. J Neurosci 14:3005-3018. Medline

Testa CM, Standaert DG, Landwehrmeyer GB, Penney JB Jr, Young AB (1995) Differential expression of mGluR5 metabotropic glutamate receptor mRNA by rat striatal neurons. J Comp Neurol 354:241-252. CrossRef Medline

Thandi S, Blank JL, Challiss RA (2002) Group-I metabotropic glutamate receptors, mGlula and mGlu5a, couple to extracellular signal-regulated kinase (ERK) activation via distinct, but overlapping, signalling pathways. J Neurochem 83:1139-1153. CrossRef Medline

Tsien RW, Lipscombe D, Madison DV, Bley KR, Fox AP (1988) Multiple types of neuronal calcium channels and their selective modulation. Trends Neurosci 11:431-438. CrossRef Medline

Uchigashima M, Narushima M, Fukaya M, Katona I, Kano M, Watanabe M (2007) Subcellular arrangement of molecules for 2-arachidonoylglycerol-mediated retrograde signaling and its physiological contribution to synaptic modulation in the striatum. J Neurosci 27:3663-3676. CrossRef Medline

Undieh AS (2010) Pharmacology of signaling induced by dopamine $D(1)-$ like receptor activation. Pharmacol Ther 128:37-60. CrossRef Medline

Valjent E, Corvol JC, Pages C, Besson MJ, Maldonado R, Caboche J (2000) Involvement of the extracellular signal-regulated kinase cascade for cocaine-rewarding properties. J Neurosci 20:8701-8709. Medline

Valjent E, Pascoli V, Svenningsson P, Paul S, Enslen H, Corvol JC, Stipanovich A, Caboche J, Lombroso PJ, Nairn AC, Greengard P, Hervé D, Girault JA (2005) Regulation of a protein phosphatase cascade allows convergent dopamine and glutamate signals to activate ERK in the striatum. Proc Natl Acad Sci U S A 102:491-496. CrossRef Medline

Vastagh C, Gardoni F, Bagetta V, Stanic J, Zianni E, Giampà C, Picconi B, Calabresi P, Di Luca M (2012) N-Methyl-D-aspartate (NMDA) receptor composition modulates dendritic spine morphology in striatal medium spiny neurons. J Biol Chem 287:18103-18114. CrossRef Medline

Voulalas PJ, Holtzclaw L, Wolstenholme J, Russell JT, Hyman SE (2005) Metabotropic glutamate receptors and dopamine receptors cooperate to enhance extracellular signal-regulated kinase phosphorylation in striatal neurons. J Neurosci 25:3763-3773. CrossRef Medline

Westin JE, Vercammen L, Strome EM, Konradi C, Cenci MA (2007) Spatiotemporal pattern of striatal ERK1/2 phosphorylation in a rat model of L-DOPA-induced dyskinesia and the role of dopamine D1 receptors. Biol Psychiatry 62:800-810. CrossRef Medline

Wiegert JS, Bading H (2011) Activity-dependent calcium signaling and ERK-MAP kinases in neurons: a link to structural plasticity of the nucleus and gene transcription regulation. Cell Calcium 49:296-305. CrossRef Medline

Xiao B, Tu JC, Worley PF (2000) Homer: a link between neural activity and glutamate receptor function. Curr Opin Neurobiol 10:370-374. Medline 